Article

\title{
Effect of 20(S)-Hydroxycholesterol on Multilineage Differentiation of Mesenchymal Stem Cells Isolated from Compact Bones in Chicken
}

\author{
Roshan Adhikari ${ }^{1}$, Chongxiao Chen ${ }^{2}$ and Woo Kyun Kim ${ }^{1, *}$ \\ 1 Department of Poultry Science, University of Georgia, 303 Poultry Science Building, Athens, GA 30602-2772, \\ USA; roshan.adhikari@cj.net \\ 2 Prestage Department of Poultry Science, North Carolina State University, 2711 Founders Drive, Raleigh, \\ NC 27695-7608, USA; sean_chen@ncsu.edu \\ * Correspondence: wkkim@uga.edu; Tel.: +1-706-248-9584; Fax: +1-706-248-9584
}

Received: 23 October 2020; Accepted: 12 November 2020; Published: 17 November 2020

\begin{abstract}
Bone health and body weight gain have significant economic and welfare importance in the poultry industry. Mesenchymal stem cells (MSCs) are common progenitors of different cell lineages such as osteoblasts, adipocytes, and myocytes. Specific oxysterols have shown to be pro-osteogenic and anti-adipogenic in mouse and human MSCs. To determine the effect of 20(S)-hydroxycholesterol (20S) on osteogenic, adipogenic, and myogenic differentiation in chicken, mesenchymal stem cells isolated from compact bones of broiler chickens (cBMSCs) were subjected to various doses of 20S, and markers of lineage-specific mRNA were analyzed using real-time PCR and cell cytochemistry. Further studies were conducted to evaluate the molecular mechanisms involved in lineage-specific differentiation pathways. Like human and mouse MSCs, 20S oxysterol expressed pro-osteogenic, pro-myogenic, and anti-adipogenic differentiation potential in cBMSCs. Moreover, 20(S)-Hydroxycholesterol induced markers of osteogenic genes and myogenic regulatory factors when exposed to cBMSCs treated with their specific medium. In contrast, $20 \mathrm{~S}$ oxysterol suppressed expression of adipogenic marker genes when exposed to cBMSCs treated with OA, an adipogenic precursor of cBMSCs. To elucidate the molecular mechanism by which 20S exerts its differentiation potential in all three lineages, we focused on the hedgehog signaling pathway. The hedgehog inhibitor, cyclopamine, completely reversed the effect of $20 \mathrm{~S}$ induced expression of osteogenic and anti-adipogenic mRNA. However, there was no change in the mRNA expression of myogenic genes. The results showed that $20 \mathrm{~S}$ oxysterol promotes osteogenic and myogenic differentiation and decreases adipocyte differentiation of cBMSCs. This study also showed that the induction of osteogenesis and adipogenesis inhibition in cBMSCs by $20 \mathrm{~S}$ is mediated through the hedgehog signaling mechanism. The results indicated that 20(S) could play an important role in the differentiation of chicken-derived MSCs and provided the theory basis on developing an intervention strategy to regulate skeletal, myogenic, and adipogenic differentiation in chicken, which will contribute to improving chicken bone health and meat quality. The current results provide the rationale for the further study of regulatory mechanisms of bioactive molecules on the differentiation of MSCs in chicken, which can help to address skeletal health problems in poultry.
\end{abstract}

Keywords: adipogenesis; chicken; mesenchymal stem cells; myogenesis; osteogenesis; 20(s)-hydroxycholesterol; hedgehog signaling

\section{Introduction}

The popularity of modern broiler meat-type chicken has grown tremendously in size in the last 60 years compared to its ancestors. However, with advanced genetic selection and increased 
production efficiency, several welfare problems such as increased leg and skeletal disorders, woody breast, and high-fat mass are challenges for the broiler industry [1-3]. Genetic selection has provided an efficient increase in growth rate and meat yield every year. However, support systems such as skeletal and cardiovascular system have not kept up with the increasing body mass, making modern broiler chicken susceptible to several welfare problems that create economic problems for the poultry industry [4]. Similarly, laying hens and breeders suffer from osteoporosis, cage layer fatigue, keel bone damage, resorption of cortical bone, increased medullary bone mass, and high abdominal fat deposition during egg production $[5,6]$. Modern laying hen strains are under negative calcium balance as soon as they enter the laying phase [7], when there is a massive demand for calcium during egg formation and a rapid turnover of medullary bones during egg production [8]. Such a process increases osteoporosis, brittle bone, breakage of the keel bone, tibia dyschondroplasia, and other skeletal problems in laying hens and breeders $[9,10]$. Changes in the housing system and the introduction of aviary and enriched cage systems have increased skeletal issues such as keel bone fracture in modern laying hens [11-13]. Bone problems are still among the costliest health disorders for the poultry industry, both in meat and egg type birds. They result in reduced feed intake, decreased weight gain, lower egg production, decreased production efficiency, increased lameness and reduced feet quality, and increased frequency of downgrades and condemnations when affected birds are processed. Bone abnormality is reported to be initiated by developmental, degenerative, nutritional, environmental, and infectious problems and this could be due to a combination of one or more of these causes [4].

Mesenchymal Stem cells derived from compact chicken bones (cBMSCs) are multipotent cells which can be a potential MSC-model to understand and address the skeletal and adipogenic health issues associated with broilers, laying hens, and breeders. Osteogenic and adipogenic cells are reported to have opposite regulations. Reduction in the number of osteoblastic cells increased bone resorption by osteoclasts, and osteoblast shift towards adipogenic cells in aging and osteoporotic cells could have caused the change in skeletal problems [14]. In various cases of osteoporosis, it has been reported that the number of adipocyte cells increases with a decrease in both the number of osteoblasts and the proliferation capacity of osteoprogenitor cells $[15,16]$. Similarly, bone loss in age-related osteoporosis could be due to the shifting of mesenchymal stem cell (MSCs) differentiation into the adipogenic pathway rather than the osteogenic pathway $[17,18]$.

MSCs are multipotent cells with high proliferation and differentiation capabilities that can differentiate into several tissue lineages such as adipocytes, osteoblasts, chondrocytes, myocytes, and fibroblasts [19-22]. MSCs are isolated from various tissue origins such as bone, adipose tissue, cord blood, placenta, as well as many other tissues [19,22-26]. MSCs isolated from bone have been reported to differentiate into several different progenitor cells, of which osteoblasts and adipocytes share a potential, reciprocal relationship in differentiation $[27,28]$. A decrease in bone formation and an increase in adipogenesis in the bone marrow could increase osteoporosis and bone fracture [29]. The decline in bone synthesis due to reduced osteoblast formation from progenitor cells, and increased adipocyte formation at the expense of those osteoblasts due to age or disease could lead to fragile bone and fracture $[30,31]$. The differentiation fate of a MSCs population is determined by the interplay of complexed extracellular mediators such as hormones, growth factors, nutrients, and pharmacological agents that affect the molecular mechanisms and signaling pathways of lineage-specific transcription factors. Regulation of stem cell fate down these various lineages is essential for tissue development, homeostasis, and repair [32]. MSCs derived from humans and mice have been used as a useful tool for studying the mineralization and differentiation potential of MSCs towards osteogenic lineage. MSCs have also been isolated from chicken bone marrow, lungs, cartilage, adipose tissue in previous studies [33-37]. However, there is limited information available to understand the multilineage differentiation potential and pathways of cBMSCs when subjected to possible osteogenic/adipogenic bioactive compounds.

Oxysterols are oxygenated derivatives of cholesterol oxidation, a 27-carbon molecule present in the circulation in human and animal tissue [38]. Oxysterol is involved in many different physiological, 
biological, and pathological roles in animals such as cholesterol efflux, lipoprotein metabolism, calcium uptake, atherosclerosis, and apoptosis [39]. It has been reported that oxysterol plays a possible role in regulating cellular differentiation of MSCs. Different oxysterol, such as 20 (S)-hydroxycholesterol (20S), alone or in combination with 22 (S) or 22 (R)-hydroxycholesterol exert pro-bone and anti-fat effects in M2-10B4 mouse bone marrow stromal cells [40]. Further studies have described that 20S oxysterol stimulated differentiation of pluripotent bone marrow stem cells derived from mouse and humans by activating hedgehog signaling in vitro [41]. Some oxysterols are potential bioactive molecules capable of suppressing adipogenic differentiation in mouse and human MSCs [42]. Oxysterols are derivatives of the endogenous cellular cholesterol biosynthesis pathway, and this pathway is essential in the osteogenic differentiation of progenitor cells. Thus, oxysterol could act as an osteoinductive compound $[43,44]$. Studies on mouse and human MSCs can be conducted to understand the effect of oxysterol, a potential bioactive compound on multilineage differentiation of cBMSCs.

There is a lack of research on understanding the combination of developmental, regenerative, and nutritional aspects to address poultry's skeletal health. Research on the skeletal health of poultry has only focused on Ca, P, and vitamin D metabolism. Studies on the effect of potentially bioactive compounds such as 20S in differentiation and the pathways involved in the differentiation of cBMSCs can help address the skeletal and adipogenic poultry issues. This study aimed to understand the effect of $20 S$ on osteogenic, adipogenic, and myogenic differentiation potential of cBMSCs and examine the possible role of hedgehog signaling pathway in multilineage differentiation in cBMSCs.

\section{Materials and Methods}

\subsection{Isolation of Compact Bone-Derived Mesenchymal Stem Cells}

All experiments and procedures involving birds were performed following the guidelines for the use of animals in research stated by the Animal Care and Use Committee at the University of Georgia (A2018 09-013). MSCs were obtained from compact bones of tibia and femur of day-old broiler chicken following a modified protocol described earlier for MSCs derived from mouse compact bone [45]. Two broiler chicks were aseptically dissected, and the legs were collected. Bone marrow was flushed with phosphate-buffered saline (PBS) containing 2\% FBS (Fisher scientific, Hampton, $\mathrm{NH}, \mathrm{USA}$ ), and compact bone was chopped into small pieces. Bones were digested with $10 \mathrm{~mL}$ Dulbecco's Modified Eagle's Medium (DMEM) (Mediatech Inc, Manassas, VA, USA) digestion buffer containing $0.25 \%$ collagenase (Sigma-Aldrich, St. Louis, MO, USA) and 20\% FBS for 55 min in a shaker at $180 \mathrm{rpm}$ and $37^{\circ} \mathrm{C}$. Contents were filtered in $100 \mathrm{~mm}$ sterile nylon meshes (Fisher scientific, USA) and centrifuged at $1200 \times g \mathrm{rpm}$ for eight $\mathrm{min}$. The supernatant was discarded, and cell pellets were suspended in $10 \mathrm{~mL}$ DMEM containing 10\% fetal bovine serum (FBS) (GE Healthcare, Chicago, IL, USA), $100 \mathrm{U} / \mathrm{mL}$ penicillin, $100 \mu \mathrm{g} / \mathrm{mL}$ streptomycin, and L-glutamate (Mediatech, Manassas, VA, USA). Cells were then seeded into $100 \mathrm{~mm}$ Petri plates (BD Bioscience, San Jose, CA, USA) and cultured at $37^{\circ} \mathrm{C}$ in a $5 \% \mathrm{CO}_{2}$ incubator. Half of the media was replaced by fresh media at $12 \mathrm{~h}$, and complete media was changed at $24 \mathrm{~h}$ to remove the non-adherent cells. After that, the media was replaced every three days until confluent.

\subsection{Cell Culture}

Cells were expanded in $10 \mathrm{~mL}$ DMEM containing 10\% FBS, $100 \mathrm{U} / \mathrm{mL}$ penicillin, $100 \mu \mathrm{g} / \mathrm{mL}$ streptomycin, and L-glutamate. Once cells were confluent, cells were washed twice with $5 \mathrm{~mL}$ PBS, trypsinized with 1X Trypsin Ethylenediaminetetraacetic acid (TE) (Mediatech, Manassas, VA, USA) at $37^{\circ} \mathrm{C}$ for two min. Eight $\mathrm{ml}$ of $10 \%$ DMEM media was added to the petri plate. Cells were washed to remove any adherent cells and transferred to a centrifuge tube. The contents were centrifuged at $1200 \times g \mathrm{rpm}$ for eight min; the supernatant was discarded, and cell pellets were plated at a rate of 20,000 cells $/ \mathrm{cm}^{2}$. All experiments were conducted between passages 4 and 5 . A series of experiments were conducted to understand the effect of $20 \mathrm{~S}$ in osteogenic, myogenic, and adipogenic differentiation 
of cBMSCs isolated from day-old broiler compact bones. Confluent cBMSCs were plated in 6-well plates and treated with different levels of assigned treatments. Confluent cells were treated with varying levels of $20 S$ along with respective differentiation media. All experiments were repeated twice to validate the results.

\subsection{Osteogenic Differentiation of cBMSCs}

Two experiments were conducted to understand the effect of $20 \mathrm{~S}$ on osteogenic differentiation of cBMSCs. In the first experiment, at passage four, confluent cBMSCs were treated with one of five treatments; (1) Control (C), (2) osteogenic media (OM) containing DMEM with 10\% FBS, $50 \mathrm{ug} / \mathrm{mL}$ ascorbate, $0.5 \mu \mathrm{M}$ dexamethasone (DXA), and $10 \mathrm{mM} \beta$-glycerophosphate, (3) OM $+2.5 \mu \mathrm{M} 20 \mathrm{~S}$, (4) $\mathrm{OM}+5 \mu \mathrm{M} 20 \mathrm{~S}$, and (5) $\mathrm{OM}+10 \mu \mathrm{M}$ 20S. Cells treated in 6-well plates were harvested at $24 \mathrm{~h}, 72 \mathrm{~h}$, and $7 \mathrm{~d}$ to examine osteogenic mRNA transcripts using quantitative reverse transcription polymerase chain reaction (qRT-PCR). Cell cytochemistry (Von Kossa and Alizarin Red) was conducted on cells cultured in 24-well plates (Greiner bio-one, Kremsmünster, Austria) at $7 \mathrm{~d}$ and $14 \mathrm{~d}$ to observe osteogenic differentiation of cells.

The second experiment was conducted to determine whether Hedgehog $(\mathrm{Hh})$ signaling pathway was involved in the molecular mechanism of osteogenic differentiation of cBMSc when treated with $20 \mathrm{~S}$. Confluent cells were pretreated with either control vehicle (Veh) or with $4 \mu \mathrm{M}$ of Hh signaling pathway inhibitor cyclopamine (Cyc) for $2 \mathrm{~h}$ followed by one of four treatments: (1) $\mathrm{C},(2)$ osteogenic media (OM) containing DMEM with 5\% FBS, $50 \mathrm{ug} / \mathrm{mL}$ ascorbate, $0.1 \mu \mathrm{M}$ DXA, and $10 \mathrm{mM} \beta$-glycerophosphate, (3) $\mathrm{OM}+10 \mu \mathrm{M} 20 \mathrm{~S}$, or (4) $10 \mu \mathrm{M} 20 \mathrm{~S}$ alone, for a total of eight treatment combinations. Cells treated with or without $\mathrm{Cyc}$ in 6-well plates were harvested at $24 \mathrm{~h}$ and $72 \mathrm{~h}$ to understand osteogenic mRNA through qRT-PCR.

\subsection{Adipogenic Differentiation of cBMSCs}

The third experiment was conducted to understand the dose-effect of $20 \mathrm{~S}$ in the adipogenic differentiation of cBMSCs. Confluent cells at passage 4 were treated with one of five treatments: (1) control (C), (2) $300 \mu \mathrm{M}$ Oleic Acid (OA), (3) OA + $2.5 \mu \mathrm{M} 20 \mathrm{~S}$, (4) OA + $5 \mu \mathrm{M}$ 20S, or (5) OA + $10 \mu \mathrm{M}$ $20 \mathrm{~S}$ for 12, 24, 48, and $96 \mathrm{~h}$. Cells cultured in 6-well plates were harvested for mRNA expression of adipogenic transcripts using qRT-PCR at 12 h, 24 h, 48 h, and 96 h. Cells were stained with Oil Red O stain to visualize lipid deposition at $48 \mathrm{~h}$.

The fourth set of experiments was conducted to evaluate whether the anti-adipogenic effects of the $20 S$ are mediated through the hedgehog signaling pathway. Confluent cells were pretreated with Veh or Cyc for $2 \mathrm{~h}$. Each pretreated group of cells was treated with C, $300 \mu \mathrm{M} \mathrm{OA}, 10 \mu \mathrm{M} 20 \mathrm{~S}$, and $300 \mu \mathrm{M} \mathrm{OA}+10 \mu \mathrm{M} 20 \mathrm{~S}$ for $24 \mathrm{~h}$ and $48 \mathrm{~h}$. Samples in 6-well plates were harvested at $24 \mathrm{~h}$ and $48 \mathrm{~h}$ to understand osteogenic mRNA transcripts using qRT-PCR.

\subsection{Myogenic Differentiation of $c B M S C S$}

The fifth set of experiments was conducted to understand the effect of $20 \mathrm{~S}$ in the myogenic differentiation of cBMSCs. cBMSCs at passage four were treated with one of five treatments: (1) C, (2) myogenic media (MM) containing DMEM with 5\% Horse Serum, $50 \mu \mathrm{M}$ Hydrocortisone, and $0.1 \mu \mathrm{M}$ DXA, (3) $\mathrm{MM}+2.5 \mu \mathrm{M}$ 20S, (4) MM+ $5 \mu \mathrm{M}$ 20S, or (5) MM + $10 \mu \mathrm{M}$ 20S. Cells in 6-well plates were harvested for evaluating mRNA expression of adipogenic transcripts using quantitative reverse transcription polymerase chain reaction (qRT-PCR) at $24 \mathrm{~h}, 72 \mathrm{~h}, 7 \mathrm{~d}$, and $14 \mathrm{~d}$.

The sixth set of experiments was conducted to evaluate Hh signaling pathway's involvement in myogenic differentiation of cBMSCs when treated with 20S. Cells were pretreated with Veh or with Cyc for $2 \mathrm{~h}$. Each pre-treated group of cells was then treated with one of four treatments: C; MM; $10 \mu \mathrm{M} 20 \mathrm{~S}$, and $\mathrm{MM}+10 \mu \mathrm{M}$ 20S. Samples in 6-well plates were harvested at $24 \mathrm{~h}$ and $72 \mathrm{~h}$ to analyze myogenic mRNA transcripts using quantitative reverse transcription polymerase chain reaction (qRT-PCR). 


\subsection{Adipocyte Differentiation-Oil Red O Stain}

Oil Red O stain was performed on harvested cells at $48 \mathrm{~h}$ to detect adipocyte differentiation following the previously described protocol $[39,46]$. In brief, cells were washed and rinsed with PBS and fixed in $60 \%$ isopropanol for two min. Cells were stained with $0.4 \%$ Oil Red O stain in $100 \%$ isopropanol for $30 \mathrm{~min}$ and rinsed with double-distilled $\mathrm{H} 2 \mathrm{O}$. After staining, cells were visualized and photographed with a microscope for red lipid droplets.

\subsection{Mineralization of Osteoblasts-Alizarin Red}

Alizarin Red test was used to detect the mineralization of osteoblasts which produces a bright orange-red color when exposed to the Alizarin red solution (Sigma Aldrich, St. Louis, MO, USA). Alizarin red test was conducted following a modified protocol, as previously described [47]. In brief, Alizarin Red Stain solution was prepared to dissolve $1 \mathrm{mg}$ of Alizarin Red S in $50 \mathrm{~mL}$ distilled water, and $\mathrm{pH}$ was adjusted to $4.1-4.3$ with $0.1 \% \mathrm{NH}_{4} \mathrm{OH}$ solution. Cells were fixed using $10 \%$ buffered formalin for $30 \mathrm{~min}$ and washed 4 times with distilled water. Cells were stained with Alizarin Red solution for $45 \mathrm{~min}$ in the dark. Cells were washed to remove the excess dye. PBS was added after washing and observed in a microscope for calcified orange/red staining.

\subsection{Osteogenic Differentiation and Calcium Deposition—Von Kossa Stain}

Von Kossa stain was used to detect the osteogenic differentiation and calcium deposition in differentiated cells. Matrix mineralization in cell monolayers was detected by silver nitrate staining, as previously described [48]. In brief, cells were washed twice with PBS, treated with 1\% glutaraldehyde, and incubated for $15 \mathrm{~min}$. Cells were washed with deionized water, and 5\% silver nitrate was added to the cells. The cells were incubated in the dark for $30 \mathrm{~min}$, washed twice with double distilled water, air dried, and exposed to bright light until black spots were developed in calcification areas.

\subsection{Quantification of $m R N A$ Expression Using $q R T-P C R$}

At the specific time point of each experiment, cells were harvested, and total RNA was isolated using Qiazol reagent (Qiagen, Hilden, Germany) following the manufacturer's protocol. Two $\mu \mathrm{g}$ of RNA was reverse transcribed using high capacity cDNA reverse transcription synthesis kits (Applied Biosystem, Atlanta, GA, USA) following the manufacturer's protocol. Primers for each gene were designed and checked for target identity using the National Centre for Biotechnology Information (NCBI). To understand the possible alteration in expression of specific transcripts in the harvested cells, qRT-PCR analysis was performed using nuclease-free water, the forward and reverse primers of each particular target gene, template cDNA, and SYBR Green (Bio-Rad, Hercules, CA, USA) using StepOne ${ }^{\mathrm{TM}}$ Real-Time PCR systems (Applied Biosystems, Foster City, CA, USA). Temperature cycles were as follows: $95^{\circ} \mathrm{C}$ for $10 \mathrm{~min}$ followed by 40 cycles at $95^{\circ} \mathrm{C}$ for $15 \mathrm{~s}$, annealing temp for $20 \mathrm{~s}$, and extension $72{ }^{\circ} \mathrm{C}$ for one minute. All analyses were done in duplicate reaction, and Glyceraldehyde 3-phosphate dehydrogenase (GAPDH) was used as a housekeeping gene for cu. After 40 cycles of qRT-PCR, melt curves were examined to ensure primer specificity. Fold changes in gene expression were calculated using the $-\Delta \Delta \mathrm{Ct}$ method and reported as fold changes of the target genes' expression in experimental groups compared to the control group. Details of primers sequences used for the experiment are presented in Table 1.

\subsection{Statistical Analysis}

Data obtained were analyzed using the general linear model procedure of the Statistics Analysis System (SAS) Institute. Tukey test was used to measure the mean separation when statistically significant. Results were analyzed and presented as means \pm SEM. The level of significance used in all three studies was a probability value of $p<0.05$. 
Table 1. Primers sequences that were used for qRT-PCR gene expression assay.

\begin{tabular}{|c|c|c|c|c|}
\hline Gene & Primer Sequence $\left(5^{\prime}-3^{\prime}\right)$ & $\begin{array}{c}\text { Product } \\
\text { Length }(\mathrm{bp})\end{array}$ & $\begin{array}{c}\text { Annealing } \\
\text { Temperature }\left({ }^{\circ} \mathrm{C}\right)\end{array}$ & Accession \# \\
\hline GAPDH & $\begin{array}{l}\text { Fwd: GCTAAGGCTGTGGGGAAAGT } \\
\text { Rev: TCAGCAGCAGCCTTCACTAC }\end{array}$ & 161 & 55 & [49] \\
\hline BSP & $\begin{array}{l}\text { Fwd: CAGTGGGAGTACGAGGTGAC } \\
\text { Rev: CAGTGGGAGTACGAGGTGAC }\end{array}$ & 141 & 55 & NM_205162.1 \\
\hline Gli1 & $\begin{array}{l}\text { Fwd: GCACAGCTCCAACGACCGCT } \\
\text { Rev: GTTGCCGTCGGAAGCACCCA }\end{array}$ & 205 & 57 & NM_001305245.1 \\
\hline BMP2 & $\begin{array}{l}\text { Fwd: TCAGCTCAGGCCGTTGTTAG } \\
\text { Rev: GTCATTCCACCCCACGTCAT }\end{array}$ & 163 & 57 & NM_204358.1 \\
\hline BGLAP & $\begin{array}{l}\text { Fwd: GACGGCTCGGATGCTCGCAG } \\
\text { Rev: CAGACGGGGCCGTAGAAGCG }\end{array}$ & 226 & 56 & [49] \\
\hline Ptch & $\begin{array}{c}\text { Fwd: GGCGTTCGCGGTGGGACTAC } \\
\text { Rev: GGTGCTGCCGGAGTGCTTCT }\end{array}$ & 205 & 56 & NM_204960.2 \\
\hline Shh & $\begin{array}{l}\text { Fwd: TGC TAG GGA TCG GTG GAT AG } \\
\text { Rev: ACA AGT CAG CCC AGA GGA GA }\end{array}$ & 197 & 56 & NM_204821.1 \\
\hline RunX2 & $\begin{array}{l}\text { Fwd: ACTTTGACAATAACTGTCCT } \\
\text { Rev: GACCCCTACTCTCATACTGG }\end{array}$ & 192 & 52 & NM_204821.1 \\
\hline FABP4 & $\begin{array}{l}\text { Fwd: TGCTGGGCATCTCAATCACA } \\
\text { Rev: GCATTAGTCAGAACGGGCCT }\end{array}$ & 106 & 57 & [49] \\
\hline $\operatorname{PPAR} \gamma$ & $\begin{array}{l}\text { Fwd: TGAATGTCGTGTGTGTGGGG } \\
\text { Rev: GCATTCGCCCAAACCTGATG }\end{array}$ & 229 & 55 & [49] \\
\hline $\mathrm{C} / \mathrm{EBP} \alpha$ & $\begin{array}{l}\text { Fwd: CCTACGGCTACAGAGAGGCT } \\
\text { Rev: GAAATCGAAATCCCCGGCCA }\end{array}$ & 205 & 55 & [49] \\
\hline $\mathrm{C} / \mathrm{EBP} \beta$ & $\begin{array}{l}\text { Fwd: CCGCTCCATGACCGAACTTA } \\
\text { Rev: GCCGCTGCCTTTATAGTCCT }\end{array}$ & 204 & 55 & [49] \\
\hline LPL & $\begin{array}{l}\text { Fwd: TGCCCCTATCCGCCTCTCCC } \\
\text { Rev: GTTGCAGCGGTAGGCCATGCT }\end{array}$ & 297 & 57 & [49] \\
\hline Col1A2 & $\begin{array}{l}\text { Fwd: AGAAAGGAATCCAGCCCAAT } \\
\text { Rev: ACACCTGCCAGATTGATTCC }\end{array}$ & 237 & 58 & NM_204426.1 \\
\hline MyoD & $\begin{array}{l}\text { Fwd: CAGCAGCTACTACACGGAATCA } \\
\text { Rev: GGAAATCCTCTCCACAATGCTT }\end{array}$ & 102 & 57 & [50] \\
\hline Myogenin & $\begin{array}{l}\text { Fwd: AGCAGCCTCAACCAGCAGGA } \\
\text { Rev: TCTGCCTGGTCATCGCTCAG }\end{array}$ & 179 & 58 & NM_204184.1 \\
\hline Pax7 & $\begin{array}{l}\text { Fwd: AGGCTGACTTCTCCATCTCTCCT } \\
\text { Rev: TGTAACTGGTGGTGCTGTAGGTG }\end{array}$ & 156 & 57 & XM_015296832.1 \\
\hline Myf5 & $\begin{array}{l}\text { Fwd: GAGGAACGCCATCAGGTACATC } \\
\text { Rev: ACATCGGAGCAGCTGGAGCT }\end{array}$ & 126 & 57 & NM_001030363.1 \\
\hline
\end{tabular}

\section{Results}

\subsection{Oxysterol Induced Osteogenic Differentiation of cBMSCs}

To elucidate the effects of $20 \mathrm{~S}$ on the osteogenic differentiation of MSCs, we examined the effects of oxysterol on osteogenic differentiation of MSCs through cell cytochemistry and gene expression analysis. Cells treated with $20 \mathrm{~S}$ induced a higher proportion of mineralization markers, Alizarin Red (Figure 1) and Von Kossa stain (Figure 2), compared to cells treated with OM and C. Moreover, $10 \mu \mathrm{M}$ of 20S significantly increased bone sialoprotein (BSP), bone morphogenic protein (BMP2), collagen type I $\alpha 2$ chain (Col1A2), sonic hedgehog (Shh), and runt-related transcription factor 2 (RunX2) expression compared to other treatment groups at $24 \mathrm{~h}$ (Figure 3A,B,D,G and H. The expression of Gli 1 was higher in cells treated with $10 \mu \mathrm{M} 20 \mathrm{~S}$ compared to control cells and cells treated with osteogenic media at all time points of the study (Figure 3C). At $24 \mathrm{~h}$, a significant increase in patched (Ptch) mRNA expression was observed in cells treated with OM and all levels of $20 \mathrm{~S}$ compared to control cells (Figure 3E). However, the inclusion of 20S did not increase Pthc expression compared to cells treated with OM. At $72 \mathrm{~h}$ and $7 \mathrm{~d}$, cells treated with $10 \mu \mathrm{M}$ of $20 \mathrm{~S}$ significantly increased Pthc mRNA expression compared to cells in C or OM treatments (Figure 3E). At $7 \mathrm{~d}$, bone $\gamma$-carboxyglutamic acid-containing protein (BGLAP) mRNA expression was significantly increased in cells treated with $10 \mu \mathrm{M}$ of 20S (Figure 3F). OM and all levels of 20S significantly increased mRNA expression of Shh. However, there was no significant difference between cells treated with OM only or 20S (Figure 3G). 
Results indicated that $10 \mu \mathrm{M} 20 \mathrm{~S}$ could induce a stimulatory effect on the osteogenic differentiation of cBMSCs.

A

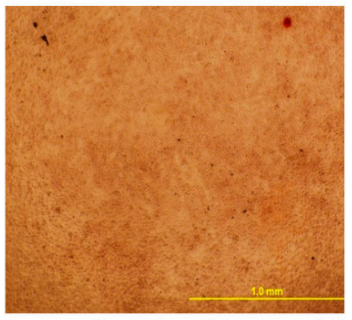

D

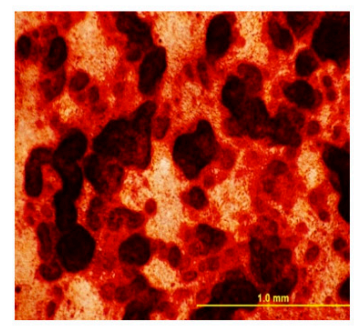

B

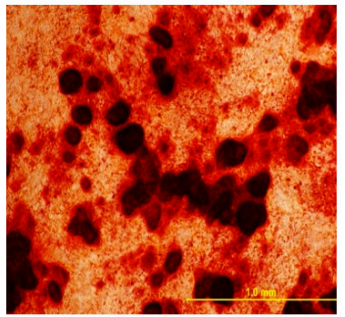

E

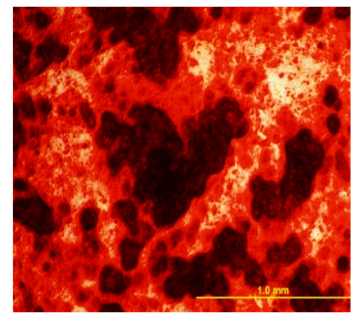

C

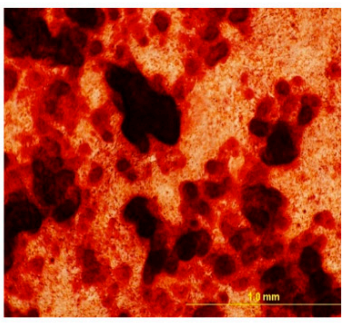

Figure 1. Mineral deposition in mesenchymal stem cells isolated from chicken compact bone stem cells treated with different levels of $20 \mathrm{~S}$ oxysterol for 14 days (detected by alizarin red test). Calcium deposition was increased in cells treated with $20 \mathrm{~S}$ oxysterol compared to control cells. Cells were treated with (A) Control (B) osteogenic media (OM) containing DMEM with 10\% FBS, $50 \mu \mathrm{g} / \mathrm{mL}$ ascorbate, $0.5 \mu \mathrm{M}$ DXA, and $10 \mathrm{mM} \beta$-glycerophosphate, (C) OM + $2.5 \mu \mathrm{M} 20 \mathrm{~S}$, (D) OM + $5 \mu \mathrm{M} 20 \mathrm{~S}$, or $(\mathrm{E}) \mathrm{OM}+10 \mu \mathrm{M}$ 20S. Pictures were taken by Olympus DP70 at $4 \mathrm{X}$.

A

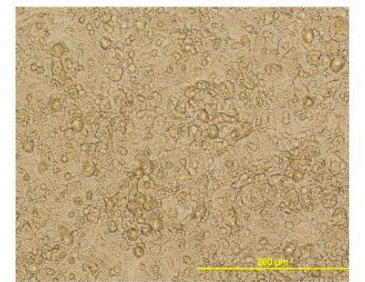

D

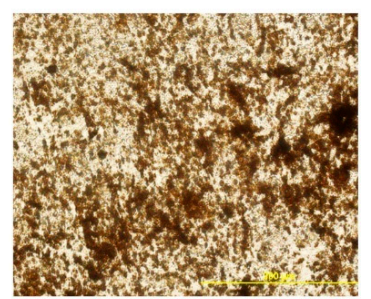

B

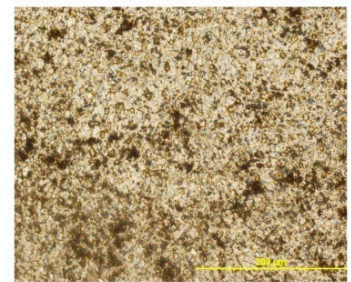

E

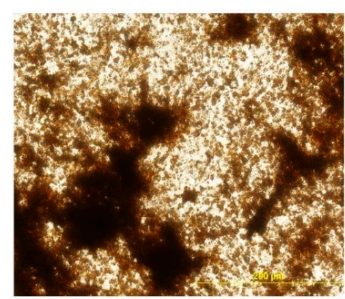

C

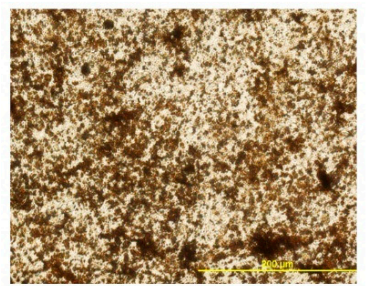

Figure 2. Mineral deposition in mesenchymal stem cells isolated from chicken compact bone stem cells treated with different levels of $20 \mathrm{~S}$ oxysterol for 14 days (detected by Von Kossa stain). Calcium deposition was increased in cells treated with $20 \mathrm{~S}$ oxysterol compared to control cells. Cells were treated with (A) Control, (B) osteogenic media (OM) containing DMEM with $10 \%$ FBS, $50 \mu \mathrm{g} / \mathrm{mL}$ ascorbate, $0.5 \mu \mathrm{M}$ DXA, and $10 \mathrm{mM} \beta$-glycerophosphate, (C) OM + $2.5 \mu \mathrm{M} 20 \mathrm{~S}$, (D) OM + $5 \mu \mathrm{M} 20 \mathrm{~S}$, or (E) $\mathrm{OM}+10 \mu \mathrm{M}$ 20S. Pictures were taken by Olympus DP70 at $20 \mathrm{X}$. 

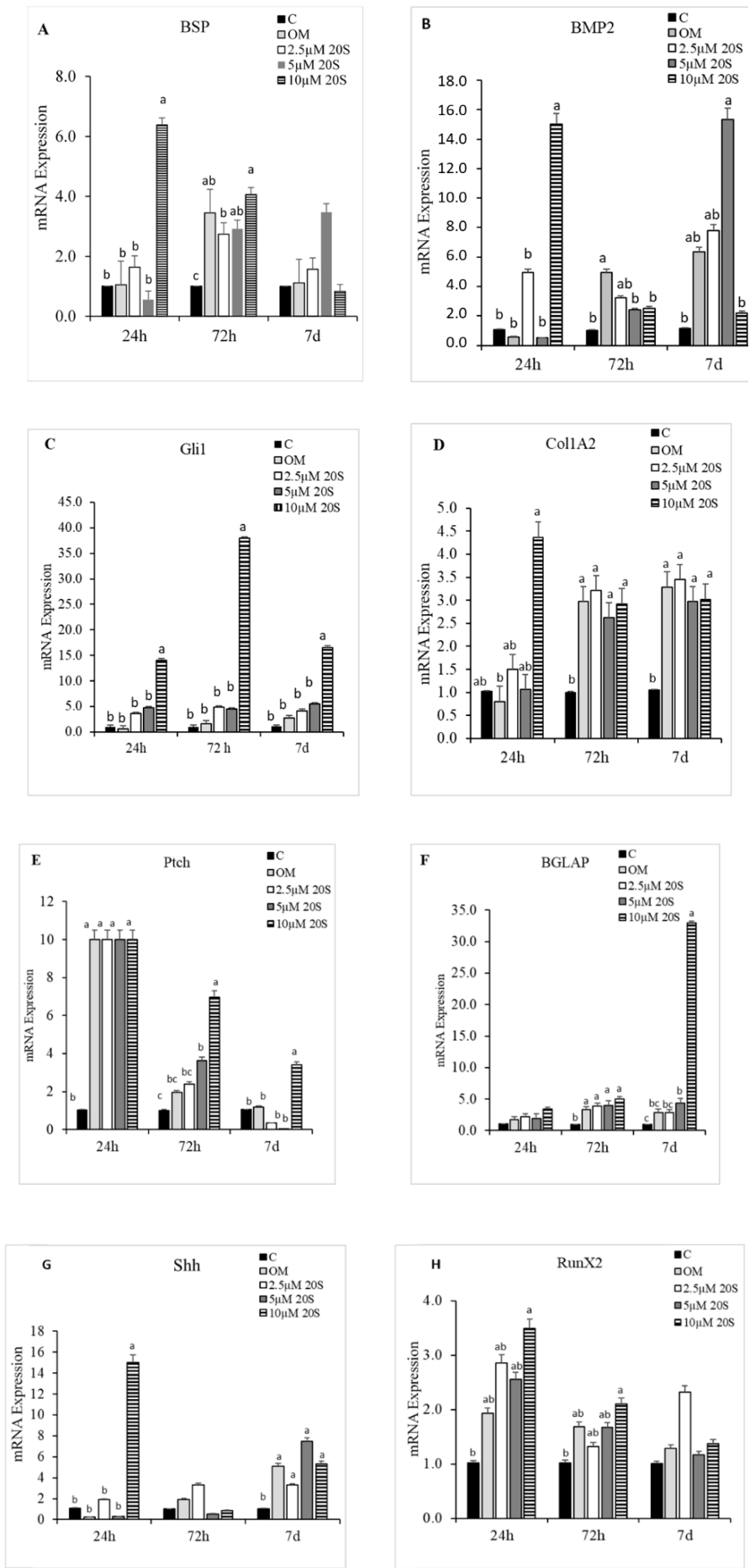

Figure 3. Osteogenic effects of $20 \mathrm{~S}$ oxysterol in mesenchymal stem cells. Relative levels of mRNA expression of osteogenic genes (A) BSP, (B) BMP2, (C) Gli-1, (D) Col1A2, (E) Ptch, (F) BGLAP, (G) Shh, and (H) RunX2 in chicken compact bone-derived mesenchymal stem cells (cBMSCs) treated with different levels of oxysterol. cBMSCs were treated with (1) Control (C), (2) osteogenic media (OM) containing DMEM with 10\% FBS, $50 \mu \mathrm{g} / \mathrm{mL}$ ascorbate, $0.5 \mu \mathrm{M}$ DXA, and $10 \mathrm{mM} \beta$-glycerophosphate, (3) $\mathrm{OM}+2.5 \mu \mathrm{M} 20 \mathrm{~S}$, (4) OM $+5 \mu \mathrm{M}$ 20S, or (5) $\mathrm{OM}+10 \mu \mathrm{M} 20 \mathrm{~S}$. Cells were harvested at $24 \mathrm{~h}, 72 \mathrm{~h}$, and $7 \mathrm{~d}$ after treatment. RNA was isolated, reverse transcribed to cDNA, and qRT-PCR was conducted to analyze osteogenic gene expression. GAPDH was used as a housekeeping gene. Fold changes in gene expression relative to the control were calculated using the $-\Delta \Delta \mathrm{Ct}$ method. Bars represent mean \pm SEM for triplicate determinations. Within each harvested period, bars without a letter $(a-b)$ in common are significantly different $(p<0.05)$ when analyzed with Tukey's test. 


\subsection{Role of Hh Signaling in Osteogenic Differentiation of cBMSCs}

To determine whether an Hh signaling mechanism is involved in regulating osteogenic differentiation in MSCs by oxysterol, 20S was added to the cBMS cells pretreated with vehicle only or cyclopamine solution. The expression of osteoblastic differentiation markers were examined $24 \mathrm{~h}$ and $72 \mathrm{~h}$ after treatment with 20S. Vec pretreated cells treated with 20S + OM had significantly increased mRNA expression of $\mathrm{Hh}$ target genes, Gli, Shh, and Pthc, at $24 \mathrm{~h}$ (Figure 4E-G). mRNA expression of other osteogenic genes, RunX2, BMP2, BSP, and BGLAP, were also significantly increased in vehicle pretreated cells treated with $\mathrm{OM}+20 \mathrm{~S}$ compared to control mediaat both $24 \mathrm{~h}$ and $72 \mathrm{~h}$ of treatment (Figure 4A-D). Cyclopamine completely reversed the effect of $\mathrm{OM}+20 \mathrm{~S}$ on the expression of osteogenic differentiation marker genes, RunX2, BMP2, BSP, BGLAP, Gli, Ptch, and Shh, at $24 \mathrm{~h}$ post-treatment (Figure 4(A1)-(G1)). Cyclopamine continued to block mRNA expression of BSP, BGLAP, and Gli1 in cells treated with $\mathrm{OM}+20 \mathrm{~S}$ up to $72 \mathrm{~h}$ of treatment (Figure 4(C2)-(E2)).
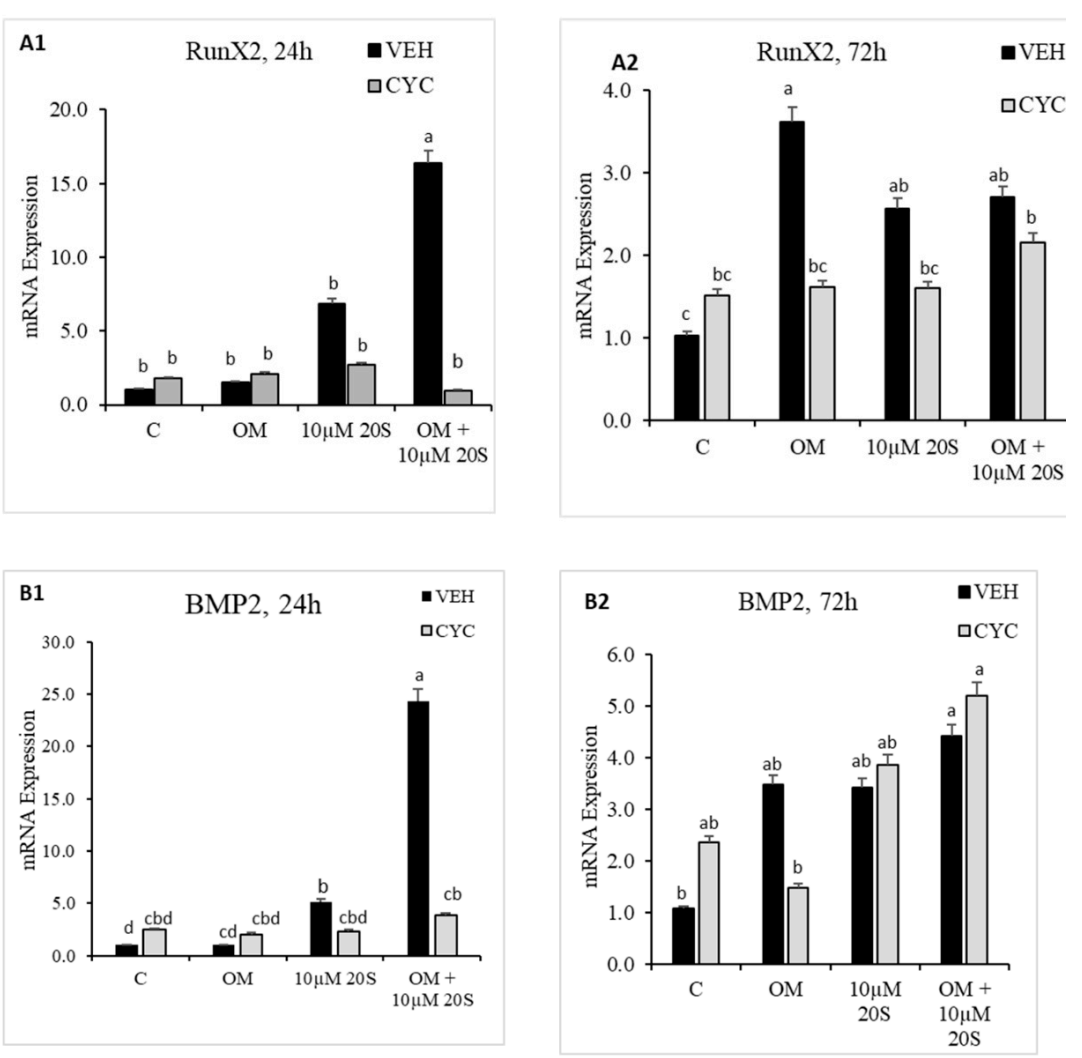

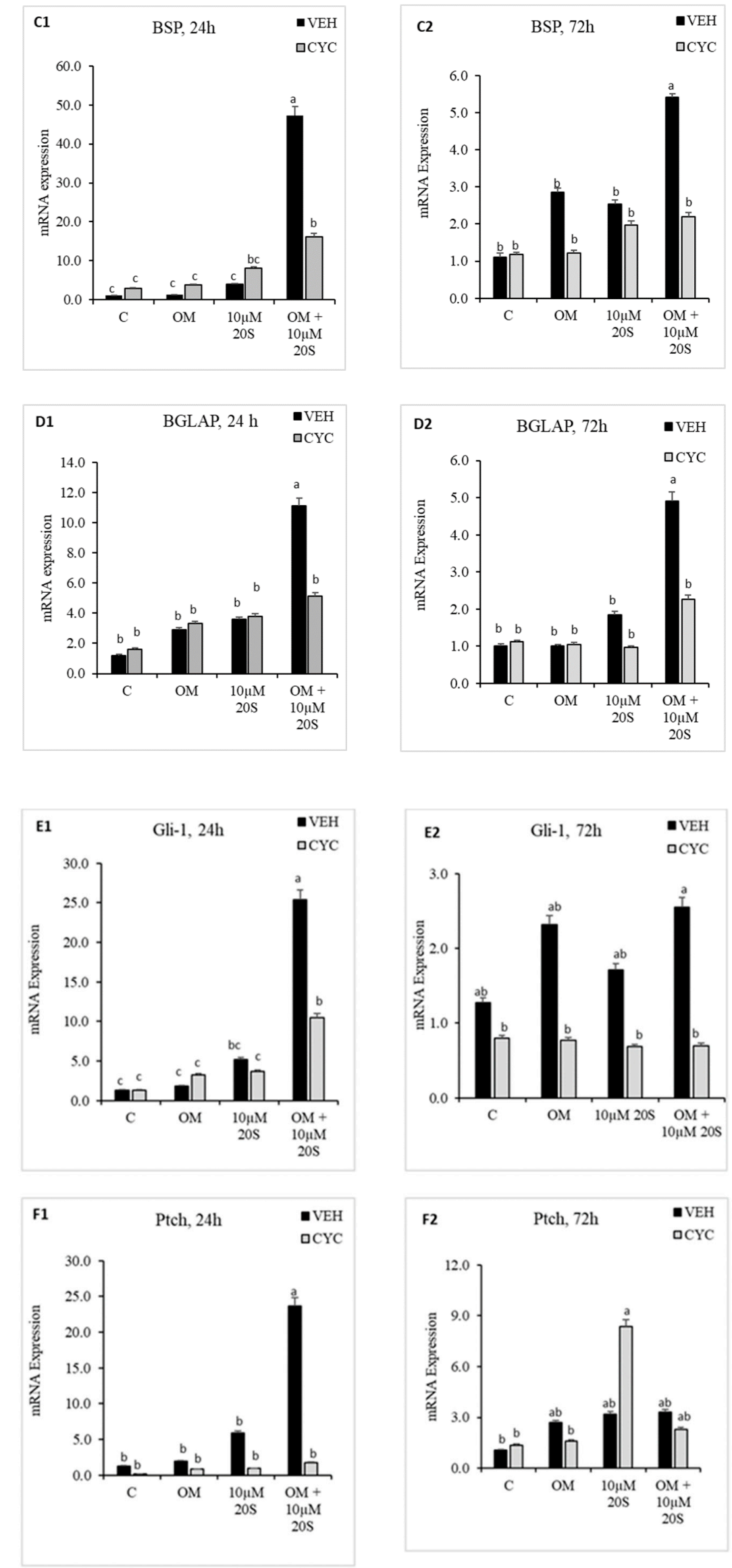

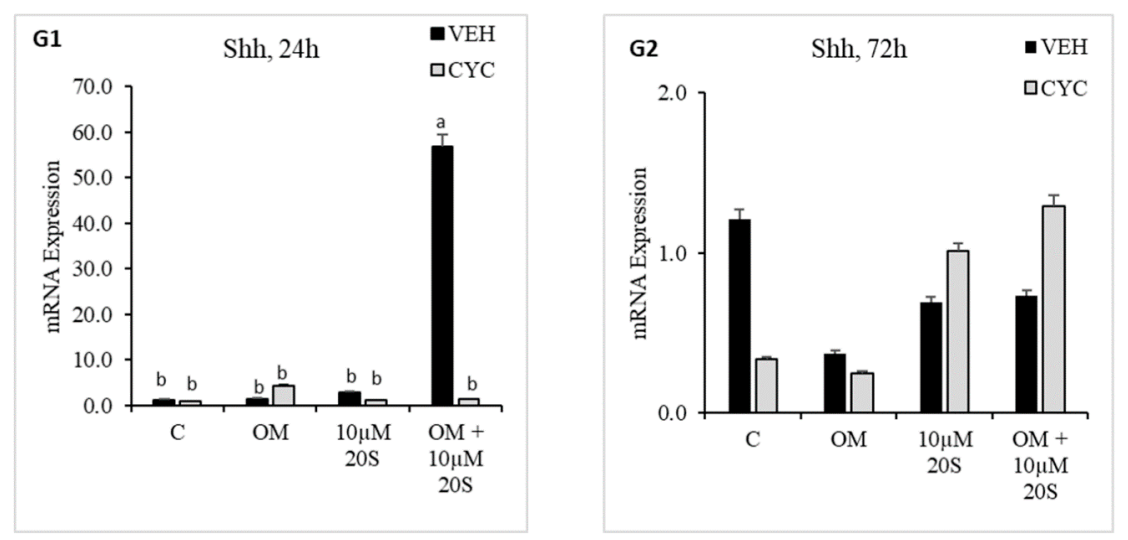

Figure 4. 20S activates osteogenic genes through the Hedgehog signaling pathway. Confluent chicken bone marrow stem cells (cBMSCs) were pretreated for $2 \mathrm{~h}$ with control vehicle (VEH) or $4 \mu \mathrm{M}$ cyclopamine (CYC), followed by $24 \mathrm{~h}$ and $72 \mathrm{~h}$ of treatment with (1) control vehicle (C), (2) osteogenic media (OM) containing DMEM with 10\% FBS, $50 \mu \mathrm{g} / \mathrm{mL}$ ascorbate, $0.5 \mu \mathrm{M}$ DXA, and $10 \mathrm{mM} \beta$-glycerophosphate, (3) $10 \mu \mathrm{M} 20 \mathrm{~S}$, or (4) $\mathrm{OM}+10 \mu \mathrm{M}$ 20S. RNA was isolated, reverse transcribed to cDNA, and qRT-PCR was conducted to analyze osteogenic gene expression. GAPDH was used as a housekeeping gene. Fold changes in gene expression relative to the control were calculated using the $-\Delta \Delta \mathrm{Ct}$ method. mRNA expression of (A1,A2) RunX2, (B1,B2) BMP2, (C1,C2) BSP, (D1,D2) BGLAP, (E1,E2) Gli-1, (F1,F2) Ptch, and $(\mathrm{G} 1, \mathrm{G} 2)$ Shh were significantly reduced in cells treated with $\mathrm{OM}+20 \mathrm{~S}$ in the Cyc pretreated group compared to the VEH pretreated group. Bars represent mean \pm SEM of triplicate determinations. Bars without a letter $(a-b)$ in common are significantly different $(p<0.05)$ when analyzed with Tukey's test.

\subsection{Effects of $20 \mathrm{~S}$ on Adipogenic Differentiation of cBMSCs}

To understand the effect of oxysterol in adipogenic differentiation of cBMSCs, we examined the effects of adipogenic genes on mRNA expression in cells treated with different doses of $20 \mathrm{~S}$ in adipogenic media. Cells treated with OA had increased adipocyte formation as detected by oil red $\mathrm{O}$ staining and quantified using a light microscope. In contrast, the inclusion of $20 \mathrm{~S}$ decreased adipocyte formation (Figure 5). Compared to control cells, cells treated with OA alone had significantly increased mRNA expression of peroxisome proliferator-activated receptor $\gamma(\operatorname{PPAR} \gamma)$, fatty acid-binding protein (FABP4), lipoprotein lipase (LPL), and CCAAT/enhancer binding protein $\beta(\mathrm{C} / \mathrm{EBP} \beta)$ at different time points during the study. OA induced expression of PPAR $\gamma$ expression at $12 \mathrm{~h}, 24 \mathrm{~h}$, and $48 \mathrm{~h}$ of treatment (Figure 6A), FABP4 expression at $48 \mathrm{~h}$ and $96 \mathrm{~h}$ of treatment (Figure 6B), and C/EBP $\beta$ (Figure 6D) at $12 \mathrm{~h}$ of treatment. Inclusion of oxysterol decreased OA-induced adipogenic mRNA expression in cBMSCs at different time points during the study. PPAR $\gamma$ mRNA expression was significantly reduced in cells treated with all three levels of $20 \mathrm{~S}$ compared to OA-treated cells at 12, 24, and $48 \mathrm{~h}$ of treatment (Figure 6A). Cells treated with $10 \mu \mathrm{M}$ of oxysterol had significantly decreased mRNA expression of FABP4 compared to cells treated with OA for 48 and $96 \mathrm{~h}$ of treatment (Figure 6B). Cells treated with $10 \mu \mathrm{M} 20 \mathrm{~S}$ had considerably reduced mRNA expression of C/EBP $\beta$ at $12 \mathrm{~h}$ and $48 \mathrm{~h}$ compared to cells treated with OA alone (Figure 6D). Results indicated that the inclusion of $20 \mathrm{~S}$ could reduce the adipogenic differentiation of cBMSCs.

\subsection{Role of Hh Signaling Mechanism in Adipogenic Signaling Pathway}

In response to previous reports regarding mouse and human MSCs about the importance of the hedgehog signaling mechanism of oxysterol in osteogenic differentiation and anti-adipogenic potential [40], we examined whether Hh signaling pathway played a role in the anti-adipogenic effects of $20 \mathrm{~S}$ in cBMSCs. OA-treated cells had significantly increased expression of FABP4 (Figure 7(A2)), PPAR $\gamma$ (Figure 7(B1)), and CEBP $\beta$ (Figure 7(D1)) at a different time points during the study. Inclusion of $20 \mathrm{~S}$ blocked the mRNA expression of FABP4 (Figure 7(A2)), PPAR $\gamma$ (Figure 7(B1)), and CEBP $\beta$ 
(Figure 7(D1)) in the cells harvested at the same time points. Cells pretreated with cyclopamine had significantly increased expression of FABP4 (Figure 7(A2)), PPAR $\gamma$ (Figure 7(B1)), CEBP $\beta$ (Figure 7(D1)), and LPL (Figure 7(E1)) at $24 \mathrm{~h}$ and FABP4 (Figure 7(A2)) at $48 \mathrm{~h}$, which was blocked by $20 \mathrm{~S}$ treatment in the Veh pretreated group (Figure 7). This study indicates that treatment with cyclopamine completely abolished the inhibitory effects of $20 \mathrm{~S}$ and increased adipogenic mRNA gene expression of FABP4, $\mathrm{c} / \mathrm{EBP} \beta, \mathrm{PPAR} \gamma$, and LPL at $24 \mathrm{~h}$ and mRNA expression of FABP 4 and PPAR $\gamma$ at $48 \mathrm{~h}$ of treatment.

\subsection{Effect of $20 \mathrm{~S}$ in Myogenic Differentiation of cBMSCs}

In addition to the effects of $20 S$ on osteogenic and adipogenic differentiation of cBMSCs, we examined the effect of $20 \mathrm{~S}$ on the myogenic differentiation potential of cBMSCs. $5 \mu \mathrm{M}$ and $10 \mu \mathrm{M}$ of $20 \mathrm{~S}$ increased MyoD mRNA expression at $72 \mathrm{~h}$ of treatment compared to control cells (Figure 8A). Inclusion of $20 \mathrm{~S}$ oxysterol increased mRNA expression of myogenic factor 5 (Myf5) compared to the control cells at $24 \mathrm{~h}$ and $72 \mathrm{~h}$ of treatment (Figure $8 \mathrm{~B}$ ). $2.5 \mu \mathrm{M}$ and $5 \mu \mathrm{M}$ of $20 \mathrm{~S}$ increased mRNA expression of Myogenin compared to control cells at $24 \mathrm{~h}$ of treatment. Cells treated with $5 \mu \mathrm{M}$ and $10 \mu \mathrm{M}$ of $20 \mathrm{~S}$ had significantly increased mRNA expression of paired box 7 (Pax7) compared to the control cell at $72 \mathrm{~h}$ of treatment. However, the expression of myogenic genes treated with oxysterol was decreased to the basal level by $7 \mathrm{~d}$ of the study.

A

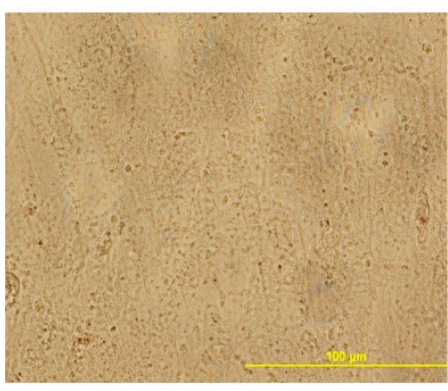

D

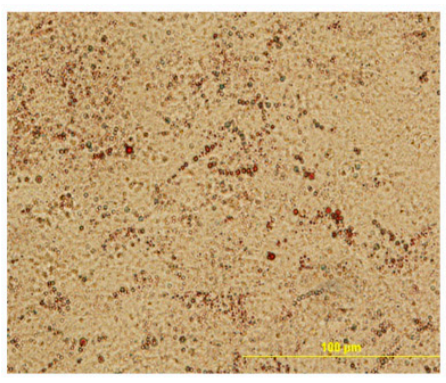

B

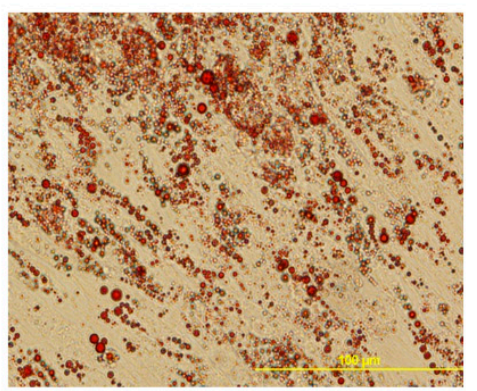

$\mathbf{E}$

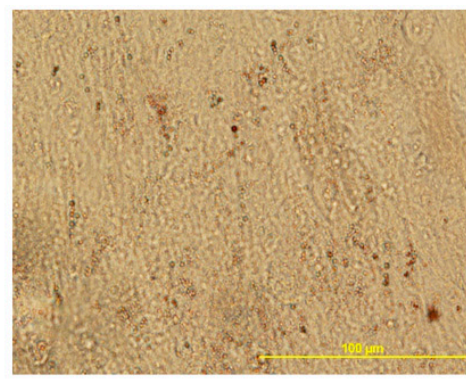

C

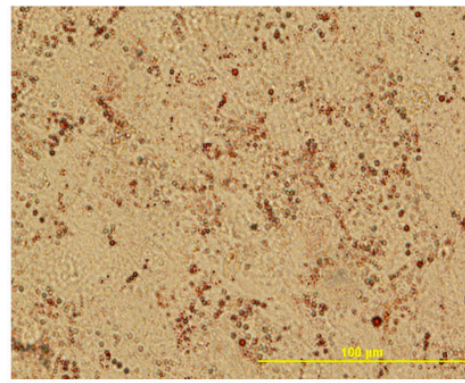

Figure 5. $20 \mathrm{~S}$ inhibits adipogenic differentiation of mesenchymal stem cells isolated from compact bones of chicken. Cells were treated with (A) Control, (B) Oleic acid media (OA), (C) OA + 2.5 $\mu$ M 20S, (D) $\mathrm{OA}+5 \mu \mathrm{M} 20 \mathrm{~S}$, or (E) OA $+10 \mu \mathrm{M} 20 \mathrm{~S}$ for $96 \mathrm{~h}$. Adipocyte formation was examined by Oil Red O staining procedure. Pictures were taken by Olympus DP70 at 20X. 

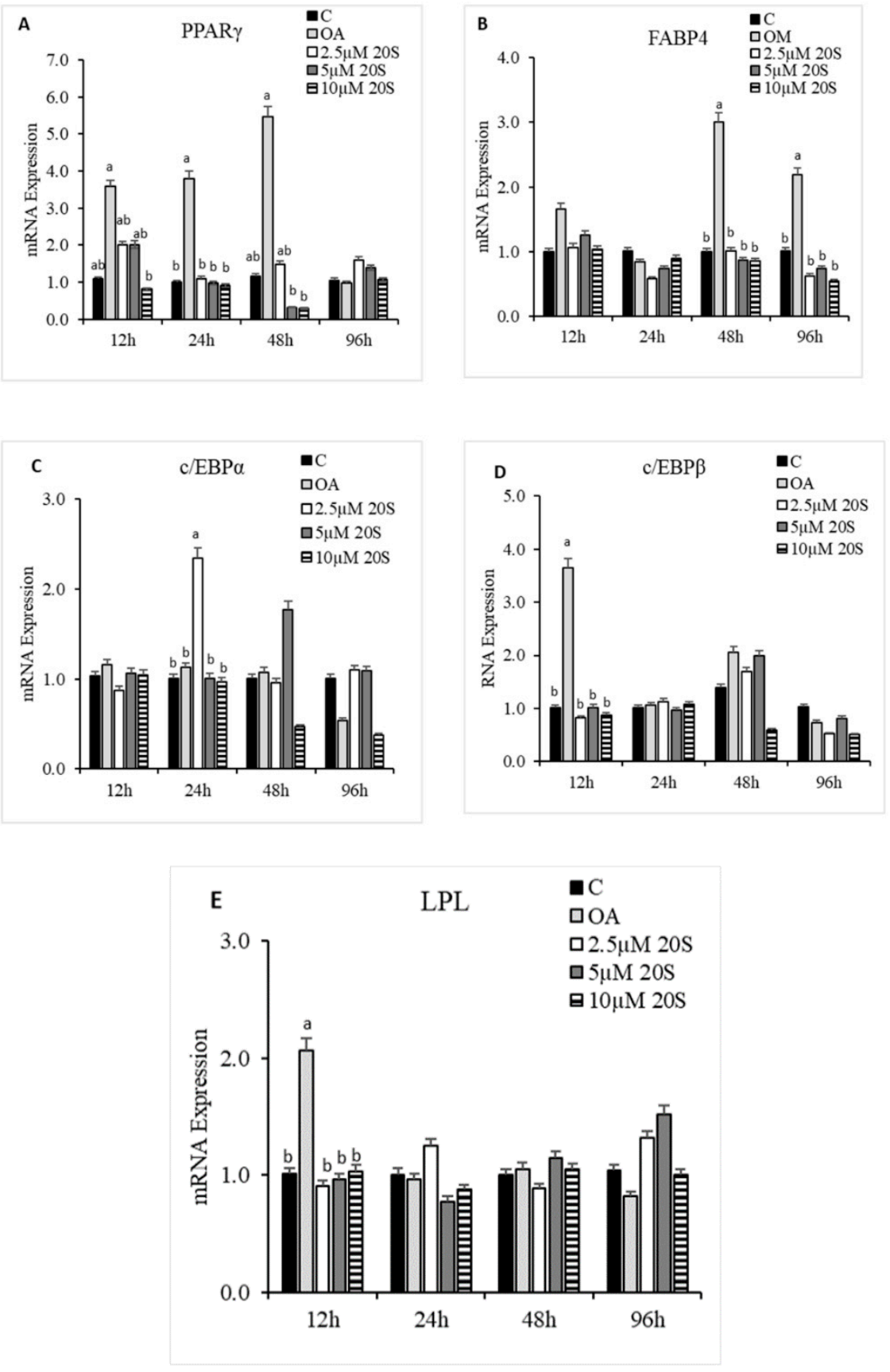

Figure 6. Adipogenic effects of 20S oxysterol on mesenchymal stem cells. Relative mRNA expression levels of osteogenic genes (A) PPAR $\gamma,(\mathbf{B})$ FABP4, (C) c/EBP $\alpha,(\mathbf{D}) \mathrm{c} / \mathrm{EBP} \beta$, and (E) LPL in compact bone-derived mesenchymal stem cells in chicken (cBMSCs) treated with different levels of oxysterol. cBMSCs were treated with (1) Control (C), (2) Oleic acid media (OA), (3) OA + 2.5 $\mathrm{MM} 20 \mathrm{~S}$, (4) OA + $5 \mu \mathrm{M}$ $20 \mathrm{~S}$, or (5) OA $+10 \mu \mathrm{M}$ 20S. Cells were harvested at $12 \mathrm{~h}, 24 \mathrm{~h}, 48 \mathrm{~h}$, and $96 \mathrm{~h}$ after treatment. RNA was isolated, reverse transcribed to cDNA, and qRT-PCR was conducted to analyze osteogenic gene expression. GAPDH was used as a housekeeping gene. Fold changes in gene expression relative to the control were calculated using the $-\Delta \Delta \mathrm{Ct}$ method. Bars represent mean $\pm \mathrm{SEM}$ of triplicate determinations. For each harvest period, bars without a letter $(a-b)$ in common within the harvested period are significantly different $(p<0.05)$ when analyzed with Tukey's test. 

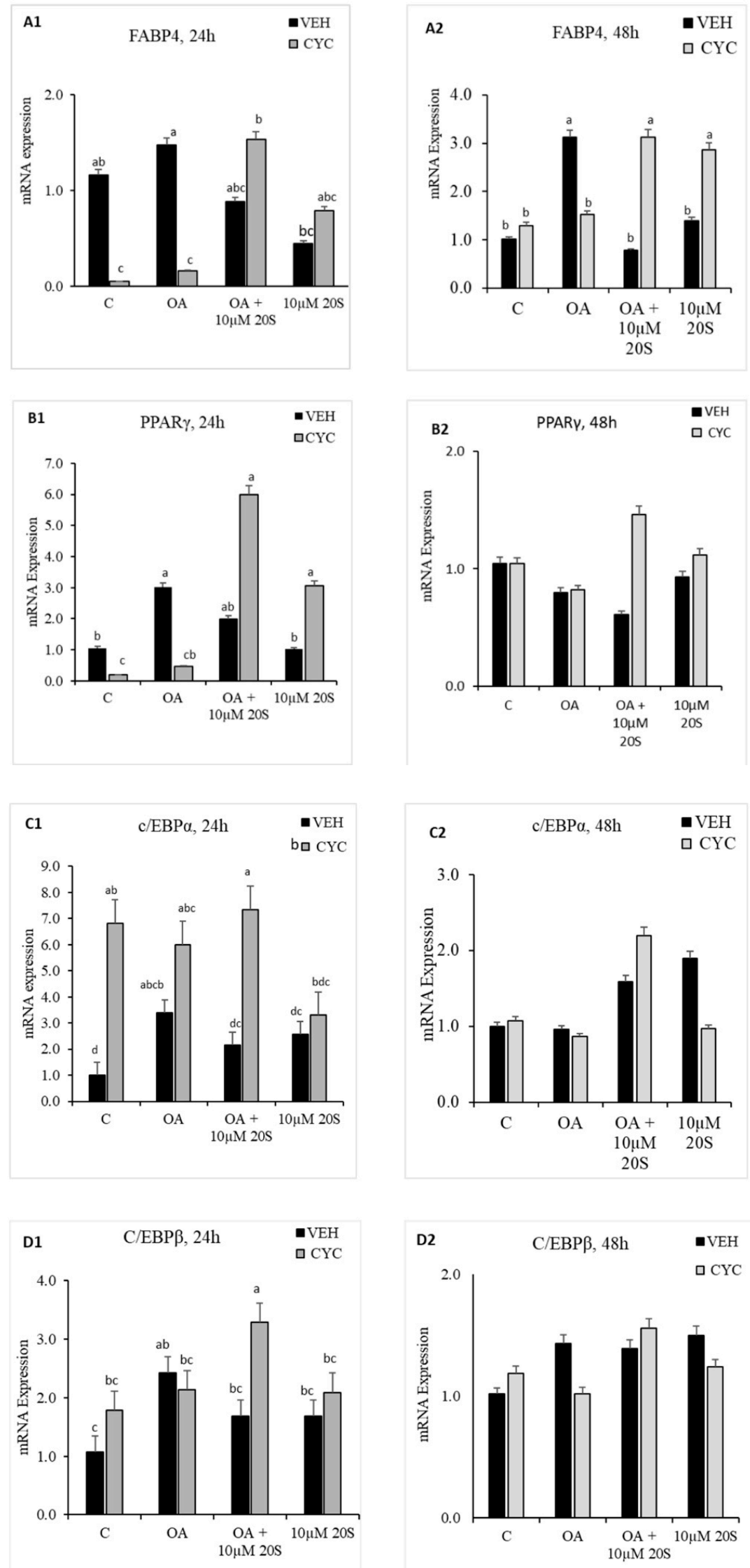

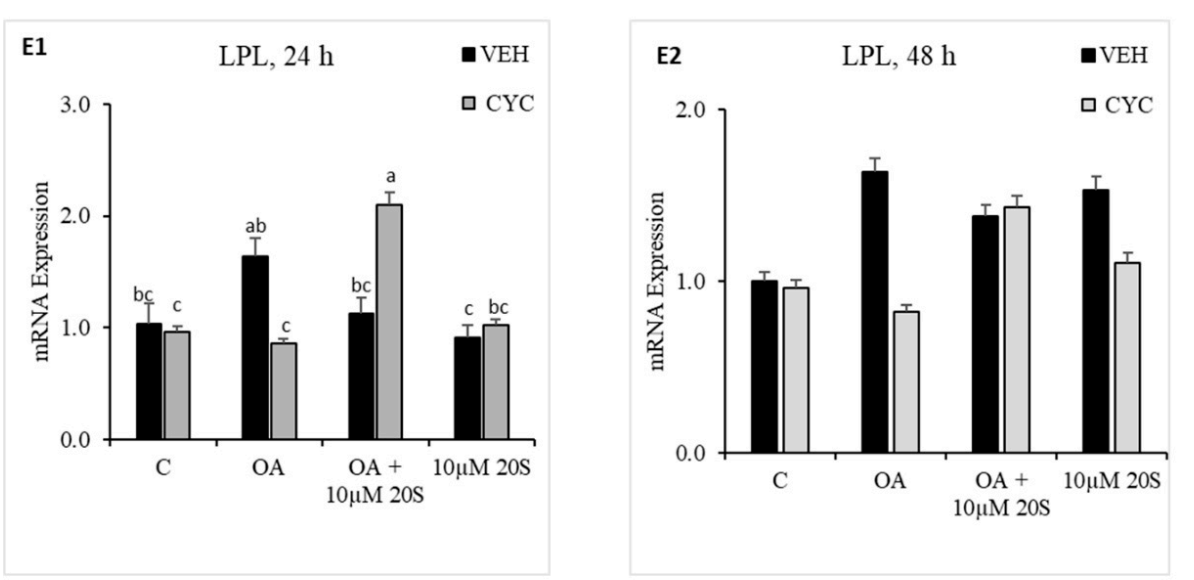

Figure 7. Hedgehog signaling pathway inhibitor, Cyclopamine, blocked the inhibitory effect of $20 \mathrm{~S}$ on OA-induced adipogenic differentiation of chicken-bone marrow stem cells (cBMSCs). When confluent, cBMSCs were pretreated for $2 \mathrm{~h}$ with control vehicle (VEH) or $4 \mu \mathrm{M}$ cyclopamine (CYC) followed by $24 \mathrm{~h}$ and $48 \mathrm{~h}$ of treatment with (1) control vehicle (C), (2) Oleic acid (OA), (3) OA + $10 \mu \mathrm{M} 20 \mathrm{~S}$, or (4) $10 \mu \mathrm{M}$ 20S. RNA was isolated, reverse transcribed to cDNA, and q RT-PCR was conducted to analyze osteogenic gene expression. GAPDH was used as a housekeeping gene. Fold changes in gene expression relative to the control were calculated using the $-\Delta \Delta \mathrm{Ct}$ method. mRNA expression of $(\mathbf{A 1}, \mathbf{A} 2)$ FABP4, (B1,B2) PPAR $\gamma,(\mathbf{C 1}, \mathbf{C} 2) \mathrm{c} / \mathrm{EBP} \alpha,(\mathbf{D 1}, \mathbf{D} 2) \mathrm{c} / \mathrm{EBP} \beta$, and $(\mathbf{E 1}, \mathbf{E} 2)$ LPL are presented above. Data from the representative experiment are reported as the mean of the triplicate determination. Bars represent mean \pm SEM for triplicate determinations. Bars without a letter $(a-b)$ in common are significantly different $(p<0.05)$ when analyzed with Tukey's test.

\subsection{Role of Hh Signaling Mechanism in Myogenic Signaling Pathway}

To determine whether Hh signaling pathway was involved in oxysterol-induced myogenic differentiation of cBMSCs, cells were pretreated with Cyc or Veh for $2 \mathrm{~h}$ before being subjected to myogenic media and 20S. In cells subjected to a combination of myogenic media and oxysterol, there was no significant difference in mRNA expression of MyoD (Figure 9(A1,A2)), Myogenin (Figure 9(B1,B2)), Myf5 (Figure 9(C1,C2)), or Pax7 (Figure 9(D1,D2)) between cells pretreated with or without cyclopamine. However, compared to pretreatment with Veh, pretreatment with cyclopamine increased expression of Pax7 mRNA at $24 \mathrm{~h}$ in cells treated with MM alone and expression of Myf5 mRNA in cells treated with 20S alone. Pretreatment with cyclopamine decreased mRNA expression of MyoD at $72 \mathrm{~h}$ compared to Veh-pretreated cells treated with myogenic media only. This study indicates that oxysterol-induced myogenic expression of cBMSCs is not mediated with the Hh signaling pathway. 
A
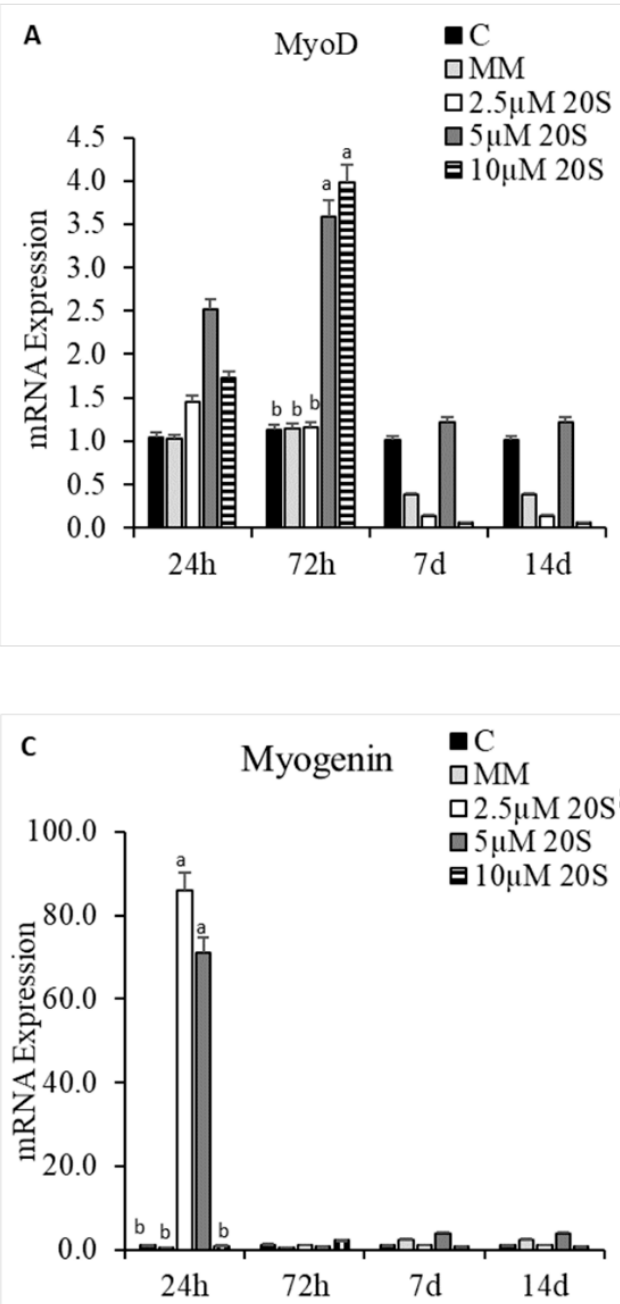
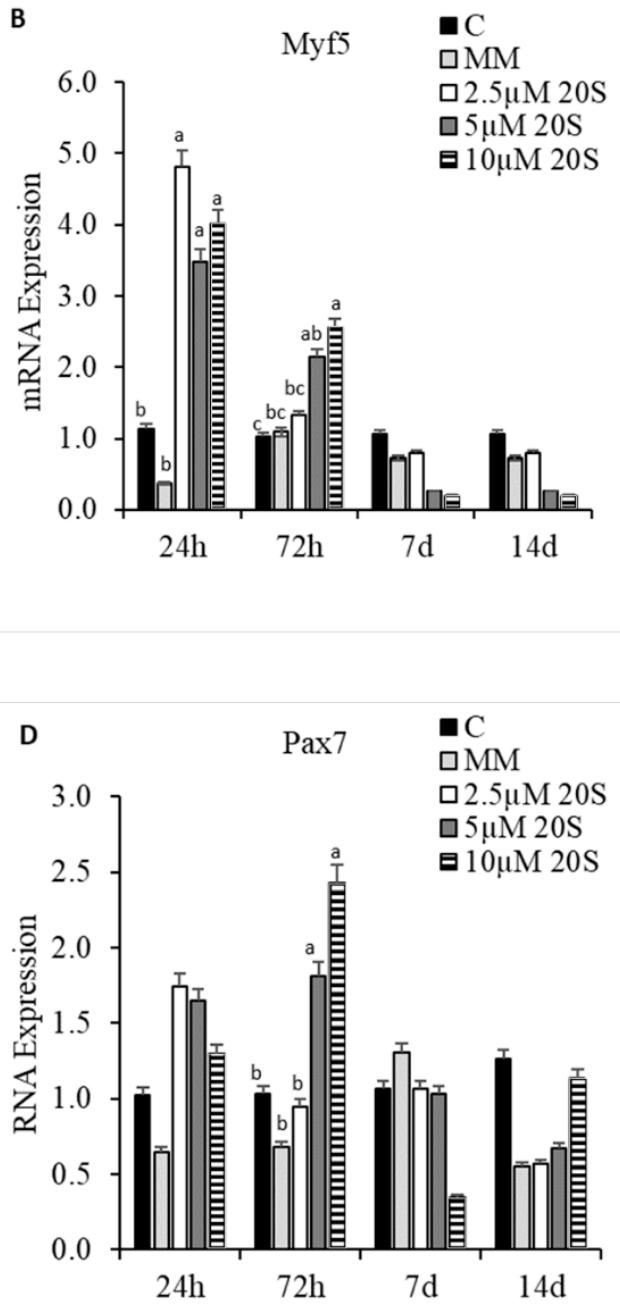

Figure 8. Myogenic effects of $20 \mathrm{~S}$ oxysterol in mesenchymal stem cells. Relative levels of mRNA expression of osteogenic genes, (A) MyoD, (B) Myf5, (C) Myogenin, and (D) Pax7, in compact bone-derived mesenchymal stem cells in chicken (cBMSCs) treated with different levels of oxysterol. cBMSCs were treated with (1) Control (C), (2) myogenic media (MM) containing DMEM with 5\% Horse Serum, $10 \mu \mathrm{M}$ Hydrocortisone, and $0.1 \mu \mathrm{M}$ DXA, (3) MM + $2.5 \mu \mathrm{M} 20 \mathrm{~S}$, (4) MM + $5 \mu \mathrm{M} 20 \mathrm{~S}$, or (5) $\mathrm{MM}+10 \mu \mathrm{M}$ 20S. Cells were harvested at $24 \mathrm{~h}, 72 \mathrm{~h}$, and $7 \mathrm{~d}$ after treatment. RNA was isolated, reverse transcribed to cDNA, and qRT-PCR was conducted to analyze osteogenic gene expression. GAPDH was used as housekeeping genes. Fold changes in gene expression relative to the control were calculated using the $-\Delta \Delta \mathrm{Ct}$ method. Bars represent mean \pm SEM of triplicate determinations. Within each harvest period, bars without a letter $(a-b)$ in common are significantly different $(p<0.05)$ when analyzed with Tukey's test. 

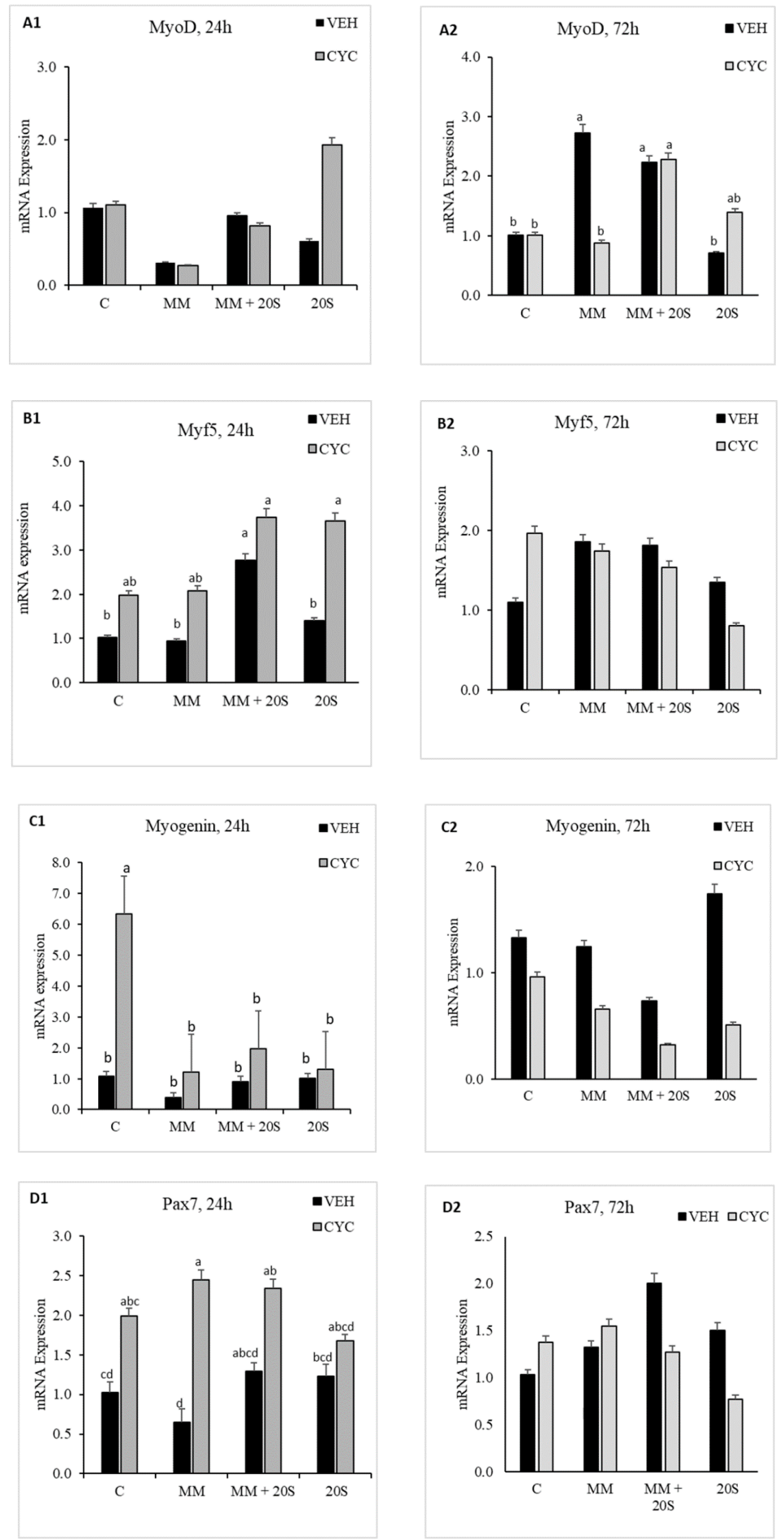

Figure 9. Hedgehog signaling pathway inhibitor, Cyclopamine, did not block the inhibitory effect of $20 \mathrm{~S}$ on myogenic differentiation of chicken bone marrow stem cells (cBMSCs). When confluent, cBMSCs were pretreated for $2 \mathrm{~h}$ with control vehicle (VEH) or $4 \mu \mathrm{M}$ cyclopamine (CYC), followed by $24 \mathrm{~h}$ and $72 \mathrm{~h}$ of treatment with (1) Control (C), (2) myogenic media (MM) containing DMEM with $5 \%$ Horse Serum, $10 \mu \mathrm{M}$ Hydrocortisone, and $0.1 \mu \mathrm{M}$ DXA, (3) MM $+2.5 \mu \mathrm{M} 20 \mathrm{~S}$, (4) $\mathrm{MM}+5 \mu \mathrm{M}$ 20S, and (5) MM + $10 \mu \mathrm{M}$ 20S. RNA was isolated, reverse transcribed to cDNA, and q RT-PCR was conducted to analyze osteogenic gene expression. GAPDH was used as a housekeeping gene. Fold changes in gene expression relative to the control were calculated using the $-\Delta \Delta \mathrm{Ct}$ method. mRNA expression of (A1,A2) MyoD, (B1,B2) Myf5, (C1,C2) Myogenin, and (D1,D2) Pax7 are presented above. Bars represent mean \pm SEM of triplicate determinations. Bars without a different letter $(a-b)$ in common are significantly different $(p<0.05)$ when analyzed with Tukey's test. 


\section{Discussion}

Primary MSCs have multilineage capacity and can differentiate to osteogenic, adipogenic, and myogenic lineages dependent on the specific cues they are subjected to. In this study, osteogenic media, adipogenic media, and myogenic media induced cBMSCs to osteogenic, adipogenic, and myogenic differentiation of cells, respectively, indicating that primary cells cultured from the compact bone in chicken are capable of multilineage differentiation. MSCs isolated from mouse and human compact bones have similar multilineage differentiation capacities. They also easily adhere to plastic surfaces $[19,51]$. Multilineage differentiation potential and ability to adhere to plastic surfaces under standard culture medium are two of the three minimum criteria that The Mesenchymal and Tissue Stem Cell Committee of the International Society for Cellular Therapy (ISCT) has published for the cells to be defined as MSCs [52].

The present study demonstrates that 20S can induce osteogenic and myogenic differentiation and reduce the adipogenic differentiation of cBMSCs. This is the first study conducted to understand oxysterol's ability to regulate osteogenic, adipogenic, and myogenic differentiation of chicken-derived stem cells. Our data strongly suggest that $10 \mu \mathrm{M} 20 \mathrm{~S}$ can induce osteogenic differentiation of cBMSCs. Detection of mineralization of osteoblasts via the Alizarin red and Von Kossa assay confirms cellular commitment towards the osteoblastic differentiation pathway and provides clear evidence of functional, mature cells [48,53]. In our study, the same assay demonstrated that cBMSCs treated with $10 \mu \mathrm{M}$ of $20 \mathrm{~S}$ had higher deposition of calcium than control cells and cells treated with OM alone. Such mineral deposits begin during extracellular matrix maturation and indicate the late stages of osteogenic differentiation of MSCs [41].

In the present study, $10 \mu \mathrm{M}$ of $20 \mathrm{~S}$ increased mRNA expression of osteogenic genes such as BSP, BMP2, col1A2, and RunX2. Run X2 is a key osteogenic gene that indicates the early commitment of MSCs to osteochondrogenic progenitor cells. RunX2 directs MSCs to differentiate into pre-osteoblast and inhibits adipogenic and chondrogenic differentiation, thereby maintaining a supply of immature osteoblasts. [54]. Immature osteoblasts express a high level of osteopontin whereas BGLAP, Col1a1, and BSP are measured in high levels when differentiated to mature osteoblasts. [55]. The mature (induced) osteoblasts show positive Von Kossa stain and Alizarin Red assay in vitro [55] as found above.

Our findings regarding mineralization and osteogenic gene expression indicate that oxysterol is a potent bioactive molecule to induce osteogenic differentiation in cBMSCs. These results agree with detailed studies of oxysterol in mouse, rabbit, and rat. A combination of 2 naturally occurring oxysterols, 20S and 22S, induced osteoinductive effects in pluripotent mouse marrow stromal cell line M2-10B4 [56,57]. Similarly, oxysterol 133 induced expression of RunX2, ALP, BSP, and BGLAP mRNA in C3H10T1/2 mouse embryonic fibroblasts and M2-10B4 mouse marrow stromal cells [58]. In the same study, oxysterol 133 increased bilateral posterolateral lumbar spinal fusion of L4-L5 in Lewis rats whose transverse process was decorticated with high-speed burr. Similarly, oxysterol 49, a novel oxysterol analog, induced osteogenic properties similar to BMP2 in rabbit bone marrow stromal cells [59].

Apart from oxysterol's osteogenic property, it is reported that oxysterol also possesses anti-adipogenic effects in mouse and human pluripotent mesenchymal stem cells [40]. In this study, OA significantly increased PPAR $\gamma$ and c/EBP $\beta$ as early as $12 \mathrm{~h}$ post treatment, which then increased the expression of FABP4 at $48 \mathrm{~h}$ and $96 \mathrm{~h}$. OA has been reported to increase adipogenic differentiation in chicken-derived MSCs rather than using DMI alone, an adipogenic cocktail used in mammalian cells differentiation [60,61]. In our study, the inclusion of 20S with OA in the cBMSCs suppressed the expression of PPAR $\gamma, \mathrm{c} / \mathrm{EBP} \beta$, and aP2 mRNA, expressions induced by OA alone. This indicates that PPAR $\gamma$ and $c / E B P \beta$ could regulate the adipogenic differentiation of cBMSCs, and the use of oxysterol could have suppressed the adipogenic differentiation by suppressing the effect of PPAR $\gamma$ or $\mathrm{c} / \mathrm{EBP} \beta$. It has been previously reported that Novel oxysterol compounds have the potential to inhibit adipocyte differentiation and decrease expression of adipogenic marker genes such as PPAR $\gamma$ in mouse and human-derived progenitor cells $[39,40]$. PPAR $\gamma$ is previously described as a key regulator of adipogenic differentiation [62]. In early adipogenesis, expression of c/EBP $\beta$ and c/EBP $\delta$ induced the 
expression of PPAR $\gamma$ and $c / E B P \alpha$ which then regulate the positive feedback mechanism that induces other genes for adipogenic differentiation. PPAR $\gamma$ is thought to also play a role in the regulation of bone metabolism. Embryonic stem cells derived from homozygous PPAR $\gamma$-deficient mice failed to show adipogenic differentiation when treated with troglitazone, whereas the expression of RunX2 and osteocalcin gene were remarkably increased [63]. Heterozygous PPAR $\gamma$-deficient mice did exhibit increased osteogenesis of cortical and trabecular bone. They had decreased adipocyte differentiation compared to wild types in vivo and in the bone marrow progenitors of those mice in vitro [63,64]. However, when a PPAR $\gamma$ expression construct was transfected to murine-derived bone marrow stromal cells and activated with hiazolidinones, the cell lines increased adipocyte differentiation. The transfer decreased the expression of RunX2 and osteocalcin [65]. In combination, these results indicate that PPAR $\gamma$ could be a key player in the adipogenesis of cBMSCs. The use of oxysterol could have suppressed adipogenic differentiation of cBMSCs by suppressing the expression of PPAR $\gamma$.

Because our results demonstrated that $20 \mathrm{~S}$ is a novel oxysterol compound that can increase osteogenic and decrease adipogenic differentiation of cBMSCs, we investigated the molecular mechanisms included and whether the Hh signaling pathway is involved. It has been reported that oxysterol is a novel activator of Hh signaling pathway to influence the osteogenic and adipogenic differentiation of mouse- and human-derived MSCs [56]. Our data provided several lines of evidence that $20 \mathrm{~S}$ could direct the osteoinductive and anti-adipogenic effects through activation of hedgehog signaling pathway. cBMSCs treated with 205 along with OM demonstrated an increase in mRNA expression of Hh target markers, such as Gli1, Ptch, and Shh. In addition, mRNA expression of osteogenic markers, such as Gli1, Pthc, BSP, RunX2, BGLAP, and BMP2, were reduced in in cBMSCs induced by 20S, but subjected to hedgehog pathway inhibitor, cyclopamine pretreatmentcompared to the mRNA expression of cBMSCs pre-treated with Veh alone. Cyclopamine continued to suppress osteogenic differentiation markers' expression until $72 \mathrm{~h}$ of the study, which suggests that the activation of Hh signaling pathway is prominent in the pro-osteogenic mechanism by which 205 regulates osteogenic differentiation of MSCs.

To elucidate the molecular mechanism by which $20 \mathrm{~S}$ inhibits the expression of adipogenic genes expressed in cBMSCs when treated with OA, we focused on Hh signaling pathway. The use of Hh signaling pathway inhibitor, cyclopamine, on cells treated with OA and $20 \mathrm{~S}$ reversed the normal inhibitory effects of $20 S$ and induced expression of adipogenic genes PPAR $\gamma, \mathrm{c} / \mathrm{EBP} \beta$, and aP2. These results indicate that $20 \mathrm{~S}$ could block PPAR $\gamma$ promoter activity stimulated by C/EBP $\beta$ through Hh signaling mechanism. Consistent with our findings in cBMSCs, $20 \mathrm{~S}$ has been reported to inhibit expression of PPAR $\gamma$ and adipogenic differentiation of M2-10B4 murine pluripotent bone marrow stromal cell lines through Hh signaling-dependent mechanism [39]. Similarly, Sonic Hedgehog (Shh) signaling pathway was reported to reduce the adipogenic differentiation of $\mathrm{C} 3 \mathrm{H} 10 \mathrm{~T} 1 / 2$ pre-adipocyte cells by decreasing the expression of $\mathrm{c} / \mathrm{EBP} \alpha$ and PPAR $\gamma$ transcription factors [66].

Hedgehog signaling pathway plays a key role in various embryonic development, growth, and patterning of tissues, postnatal development and maintenance of tissue/organ integrity and function, stem cell physiology, cancer, and cardiovascular disease [41]. There are three members of Hh family: Indian Hh, Sonic Hh, and Desert Hh. Hh signaling involves a complex array of factors that influences the function and distribution of $\mathrm{Hh}$ molecules. Hedgehog signaling begins with the binding of hedgehog protein to a transmembrane protein Patch, which removes the inhibitory effects on another transmembrane protein, Smo, in Hh responsive cells [67]. Smo activates the intracellular signaling cascade, resulting in activation of Gli transcription factors, which transcribe the Hh target genes, Gli-1 and Ptch [56]. This transcription regulation involves the Ci/Gli transcription factors and intricate interaction among membranes of a complex accessory molecule including Fused, suppressor of fused, and Rab 23 to regulate localization and stability of Gli [67]. Previous experiments in mice reported that lacking Indian $\mathrm{Hh}$ resulted in the disorder of endochondral bone patterning and osteoblast formation. Those mice lacking sonic hedgehog showed disorders in craniofacial bones, vertebral column, and calcified ribs [68,69]. Previous studies have also reported that the lineage-specific 
osteogenic differentiation of MSCs is controlled by Hh signaling mechanism [70,71]. Furthermore, there are several reports of other bioactive compounds that regulate osteogenic and adipogenic differentiation of MSCs derived from humans and mice through Hh signaling [72,73].

Previous studies have reported that different forms of oxysterol, such as oxy 49, oxy 133, 20S, and 22S induced osteogenic expression and reduced adipogenic expression potential of MSCs derived from mouse and human cells through Hh signaling mechanism [39,41,53,56,58,74,75]. Further studies in mouse and human MSCs have indicated that oxysterol could induce osteogenic differentiation of mouse and human stromal cells through other pathways: a Wnt signaling related, Dkk-1-inhinitable and PI3-kinase mechanism [76], activation of HES-1 and HEY-1 expression, and LXR activation pathway [41]. Studies in mouse NIH-3T3 fibroblast, C3H10T1/2 MSCs, and 3T3-L1 preadipocytes have shown that Hh signaling blocks the early step of adipogenesis upstream of PPAR $\gamma$, presumably after mitotic clonal expansion, by regulating Gata expression [77]. This indicates that the anti-adipogenic effect through Hh signaling could be regulated at least in part by Gata expression.

Several in vitro studies have demonstrated that, in vitro, MSCs can interconvert between osteoblast and adipocyte phenotypes [78]. In addition, it has been reported that, under appropriate conditions, mature osteoblasts can undergo adipogenesis [30] and mature adipocytes have been differentiated along the osteoblastic pathway. Several studies demonstrate an inverse relationship between osteoblast and adipocyte differentiation. TAZ increased the transcription of RunX2-dependent gene and decreased expression of PPAR $\gamma$, thus promoting osteogenesis and reducing adipogenesis [79]. Similarly, Dlk1 has been reported to be involved in the regulatory effects of both osteoblast and adipocyte differentiation of human-derived MSCs [80]. It has also been described that oxysterols affect cyclo-oxygenase and phospholipase A2 and act in synergy with bMP2 in inhibiting adipogenesis and inducing osteogenic differentiation [40]. It has been described that $20 \mathrm{~S}$ could cause a pro-osteogenic effect on MSCs by Hh signaling through activating expression of Notch target genes Hes-1, HEY-1, and HEY-2 in bone marrow stem cells [41].

Notch target genes are involved in various biological processes, including osteogenesis, adipogenesis, and myogenesis. Our study demonstrated that $20 \mathrm{~S}$ oxysterol significantly increased myogenic expression of MyoD, Myogenin, MyF5, and Pax7 mRNA expression. A previous study in human umbilical cord-derived MSCs showed MyoD and Myogenin were expressed as early as 3 days after incubation with myogenic media, but were not expressed after two weeks of culture [81]. Myogenic differentiation of MSCs occurs via activation of myogenic transcription factors: PAX3, MyoD, Myf-5, and Myogenin [82,83]. Pax3 and Pax7 are master regulators of myogenic differentiation and contribute to early striated muscle development during skeletal muscle differentiation [84]. cBMSCs pretreated with the Hh signaling inhibitor cyclopamine, did not show a decrease in the expression of myogenic transcription factors indicating that $\mathrm{Hh}$ signaling did not play a role in controlling myogenic regulation by $20 \mathrm{~S}$ oxysterol.

Myogenesis is regulated by a family of transcription factors, including MyoD, Myogenin, Myf5, and MRF4 $[85,86]$. Skeletal myogenesis is the developmental cascade that involves the regulatory MyoD gene family that determines the progress of multipotent mesodermal stem/progenitor cells into myogenic lineage [87]. Skeletal muscle stem cells are composed of multinucleated myofibers established during embryogenesis by the fusion of myogenic cells, also called satellite cells [88]. Satellite cells are considered as precursors for muscle growth and repair. Typically, the myofiber nuclei are mitotically inactive, but they are activated to respond to muscle damage and provide progeny cells for myofiber repair and growth. Thus, satellite cells exhibit stem cell-like properties and are competent to form the basal origin of muscle regeneration [89]. Myogenesis of satellite cells is regulated by muscle-specific regulatory factors such as MyoD, Myf5, and Myogenin. Mouse satellite cells and myogenic cell lines express Myf5 protein in proliferating cells, whereas the protein was not detected upon differentiation and fusion with myotubes [90]. The expression of $\mathrm{MyoD}$ is observed during satellite-cell proliferation, whereas their differentiation is marked by the expression of Myogenin with a decrease in PAx7 and Myf5 [90,91]. Skeletal myogenesis is a developmental cascade, where MyoD 
family and myogenic regulator factors directly regulate myocyte cell specification, differentiation, and expression at the early stage of myogenic differentiation $[81,86]$. Mutant mice that lack MyoD and dystrophin displayed a significant increase in the severity of myopathy and premature death, highlighting the role of $\mathrm{MyoD}$ in muscle regeneration [84]. In a previous study, the treatment of muscle cells derived stem cells indicates that incubation of satellite cells with 1-25-D3 increased myogenic markers such as MyoD, Myogenin, MYH1, and muscle troponin [65].

\section{Conclusions}

In summary, this study shows that $20 \mathrm{~S}$ is an oxysterol compound with pro-osteogenic, pro-myogenic, and anti-adipogenic properties in cBMSCs. Our study further provides evidence that $20 \mathrm{~S}$ increased the osteogenic differentiation and decreased adipogenic differentiation of cBMSCs. And the actions of $20 \mathrm{~S}$ were involved inHh signaling pathway. Furthermore, $20 \mathrm{~S}$ oxysterol also increased the myogenic differentiation of cBMSCs, but did not exert its differentiation through Hh signaling pathway. These findings provide evidence that oxysterols could induce the Hh signaling pathway and, therefore, could play an important role in other developmental processes in chicken. Further study needs to be conducted to improve our understanding of the detailed molecular mechanisms and downstream targets of oxysterol in cBMSCs. This research could lead to novel oxysterol compounds and intervention therapies targeting MSCs regeneration/lineage differentiation to tackle skeletal-, adipose-, and muscle-derived problems in poultry with economic and welfare implications for the industry.

Author Contributions: Conceptualization, W.K.K.; methodology, R.A. and C.C.; software, A.R. and C.C.; validation, W.K.K., A.R., and C.C.; formal analysis, A.R.; investigation, A.R., C.C., and W.K.K.; resources, W.K.K.; data curation, W.K.K. and A.R.; writing-original draft preparation, A.R. and C.C.; writing-review and editing, W.K.K.; visualization, A.R. and C.C.; supervision, W.K.K.; project administration, W.K.K.; funding acquisition, W.K.K. All authors have read and agreed to the published version of the manuscript.

Funding: This research was funded by USDA-NIFA (\#2017-67015-26586).

Conflicts of Interest: The authors declare no conflict of interest.

\section{References}

1. Bailey, R.A.; Watson, K.A.; Bilgili, S.F.; Avendano, S. The genetic basis of pectoralis major myopathies in modern broiler chicken lines. Poult. Sci. 2015, 94, 2870-2879. [CrossRef] [PubMed]

2. Julian, R.J. Rapid growth problems: Ascites and skeletal deformities in broilers. Poult. Sci. 1998, 77, 1773-1780. [CrossRef] [PubMed]

3. Knowles, T.G.; Kestin, S.C.; Haslam, S.M.; Brown, S.N.; Green, L.E.; Butterworth, A.; Pope, S.J.; Pfeiffer, D.; Nicol, C.J. Leg Disorders in Broiler Chickens: Prevalence, Risk Factors and Prevention. PLoS ONE 2008, 3, e1545. [CrossRef] [PubMed]

4. Dibner, J.J.; Richards, J.D.; Kitchell, M.L.; Quiroz, M.A. Metabolic Challenges and Early Bone Development. J. Appl. Poult. Res. 2007, 16, 126-137. [CrossRef]

5. Nasr, M.A.; Murrell, J.; Nicol, C.J. The effect of keel fractures on egg production, feed and water consumption in individual laying hens. Br. Poult. Sci 2013, 54, 165-170. [CrossRef]

6. Bain, M.M.; Nys, Y.; Dunn, I.C. Increasing persistency in lay and stabilising egg quality in longer laying cycles. What are the challenges? Br. Poult. Sci. 2016, 57, 330-338. [CrossRef]

7. Neijat, M.; House, J.D.; Guenter, W.; Kebreab, E. Calcium and phosphorus dynamics in commercial laying hens housed in conventional or enriched cage systems. Poult. Sci. 2011, 90, 2383-2396. [CrossRef]

8. Kim, W.K.; Bloomfield, S.A.; Sugiyama, T.; Ricke, S.C. Concepts and methods for understanding bone metabolism in laying hens. World's Poult. Sci. J. 2012, 68, 71-82. [CrossRef]

9. Whitehead, C.C.; Fleming, R.H. Osteoporosis in cage layers. Poult. Sci. 2000, 79, 1033-1041. [CrossRef]

10. Regmi, P.; Nelson, N.; Steibel, J.P.; Anderson, K.E.; Karcher, D.M. Comparisons of bone properties and keel deformities between strains and housing systems in end-of-lay hens. Poult. Sci. 2016, 95, 2225-2234. [CrossRef] 
11. Nicol, C.J.; Brown, S.N.; Glen, E.; Pope, S.J.; Short, F.J.; Warriss, P.D.; Zimmerman, P.H.; Wilkins, L.J. Effects of stocking density, flock size and management on the welfare of laying hens in single-tier aviaries. Br. Poult. Sci 2006, 47, 135-146. [CrossRef] [PubMed]

12. Petrik, M.T.; Guerin, M.T.; Widowski, T.M. On-farm comparison of keel fracture prevalence and other welfare indicators in conventional cage and floor-housed laying hens in Ontario, Canada. Poult. Sci. 2015, 94, 579-585. [CrossRef]

13. Heerkens, J.L.; Delezie, E.; Rodenburg, T.B.; Kempen, I.; Zoons, J.; Ampe, B.; Tuyttens, F.A. Risk factors associated with keel bone and foot pad disorders in laying hens housed in aviary systems. Poult. Sci. 2016, 95, 482-488. [CrossRef] [PubMed]

14. Chan, G.K.; Duque, G. Age-related bone loss: Old bone, new facts. Gerontology 2002, 48, 62-71. [CrossRef] [PubMed]

15. Nuttall, M.E.; Gimble, J.M. Is there a therapeutic opportunity to either prevent or treat osteopenic disorders by inhibiting marrow adipogenesis? Bone 2000, 27, 177-184. [CrossRef]

16. Stenderup, K.; Justesen, J.; Clausen, C.; Kassem, M. Aging is associated with decreased maximal life span and accelerated senescence of bone marrow stromal cells. Bone 2003, 33, 919-926. [CrossRef]

17. Muruganandan, S.; Roman, A.A.; Sinal, C.J. Adipocyte differentiation of bone marrow-derived mesenchymal stem cells: Cross talk with the osteoblastogenic program. Cell. Mol. Life Sci. 2009, 66, 236-253. [CrossRef]

18. Takada, I.; Kouzmenko, A.P.; Kato, S. Molecular switching of osteoblastogenesis versus adipogenesis: Implications for targeted therapies. Expert Opin. Ther. Targets 2009, 13, 593-603. [CrossRef]

19. Pittenger, M.F.; Mackay, A.M.; Beck, S.C.; Jaiswal, R.K.; Douglas, R.; Mosca, J.D.; Moorman, M.A.; Simonetti, D.W.; Craig, S.; Marshak, D.R. Multilineage potential of adult human mesenchymal stem cells. Science 1999, 284, 143-147. [CrossRef]

20. Barry, F.P.; Murphy, J.M. Mesenchymal stem cells: Clinical applications and biological characterization. Int. J. Biochem. Cell Biol. 2004, 36, 568-584. [CrossRef]

21. Bellotti, C.; Duchi, S.; Bevilacqua, A.; Lucarelli, E.; Piccinini, F. Long term morphological characterization of mesenchymal stromal cells 3D spheroids built with a rapid method based on entry-level equipment. Cytotechnology 2016, 68, 2479-2490. [CrossRef]

22. Sanjurjo-Rodriguez, C.; Castro-Vinuelas, R.; Hermida-Gomez, T.; Fernandez-Vazquez, T.; Fuentes-Boquete, I.M.; de Toro-Santos, F.J.; Diaz-Prado, S.M.; Blanco-Garcia, F.J. Ovine Mesenchymal Stromal Cells: Morphologic, Phenotypic and Functional Characterization for Osteochondral Tissue Engineering. PLoS ONE 2017, 12, e0171231. [CrossRef] [PubMed]

23. Friedenstein, A.J.; Chailakhyan, R.K.; Gerasimov, U.V. Bone marrow osteogenic stem cells: In vitro cultivation and transplantation in diffusion chambers. Cell Tissue Kinet. 1987, 20, 263-272. [CrossRef] [PubMed]

24. Weiss, M.L.; Troyer, D.L. Stem cells in the umbilical cord. Stem Cell Rev. 2006, 2, 155-162. [CrossRef]

25. Fellows, C.R.; Matta, C.; Zakany, R.; Khan, I.M.; Mobasheri, A. Adipose, Bone Marrow and Synovial Joint-Derived Mesenchymal Stem Cells for Cartilage Repair. Front. Genet. 2016, 7, 213. [CrossRef] [PubMed]

26. Hoffmann, A.; Floerkemeier, T.; Melzer, C.; Hass, R. Comparison of in vitro-cultivation of human mesenchymal stroma/stem cells derived from bone marrow and umbilical cord. J. Tissue Eng. Regen. Med. 2017, 11, 2565-2581. [CrossRef] [PubMed]

27. Park, S.R.; Oreffo, R.O.; Triffitt, J.T. Interconversion potential of cloned human marrow adipocytes in vitro. Bone 1999, 24, 549-554. [CrossRef]

28. Kassem, M.; Abdallah, B.M.; Saeed, H. Osteoblastic cells: Differentiation and trans-differentiation. Arch. Biochem. Biophys. 2008, 473, 183-187. [CrossRef]

29. Jilka, R.L.; Weinstein, R.S.; Takahashi, K.; Parfitt, A.M.; Manolagas, S.C. Linkage of decreased bone mass with impaired osteoblastogenesis in a murine model of accelerated senescence. J. Clin. Investig. 1996, 97, 1732-1740. [CrossRef]

30. Nuttall, M.E.; Patton, A.J.; Olivera, D.L.; Nadeau, D.P.; Gowen, M. Human trabecular bone cells are able to express both osteoblastic and adipocytic phenotype: Implications for osteopenic disorders. J. Bone Miner. Res. Off. J. Am. Soc. Bone Miner. Res. 1998, 13, 371-382. [CrossRef]

31. Singh, L.; Brennan, T.A.; Russell, E.; Kim, J.H.; Chen, Q.; Brad Johnson, F.; Pignolo, R.J. Aging alters bone-fat reciprocity by shifting in vivo mesenchymal precursor cell fate towards an adipogenic lineage. Bone 2016, 85, 29-36. [CrossRef] [PubMed] 
32. Oh, J.; Lee, Y.D.; Wagers, A.J. Stem cell aging: Mechanisms, regulators and therapeutic opportunities. Nat. Med. 2014, 20, 870-880. [CrossRef] [PubMed]

33. Khatri, M.; O’Brien, T.D.; Goyal, S.M.; Sharma, J.M. Isolation and characterization of chicken lung mesenchymal stromal cells and their susceptibility to avian influenza virus. Dev. Comp. Immunol. 2010, 34, 474-479. [CrossRef] [PubMed]

34. Khatri, M.; O'Brien, T.D.; Sharma, J.M. Isolation and differentiation of chicken mesenchymal stem cells from bone marrow. Stem. Cells Dev. 2009, 18, 1485-1492. [CrossRef]

35. Li, L.; Ma, Y.; Li, X.; Li, X.; Bai, C.; Ji, M.; Zhang, S.; Guan, W.; Li, J. Isolation, Culture, and Characterization of Chicken Cartilage Stem/Progenitor Cells. Biomed. Res. Int. 2015, 2015, 586290. [CrossRef] [PubMed]

36. Bai, C.; Hou, L.; Ma, Y.; Chen, L.; Zhang, M.; Guan, W. Isolation and characterization of mesenchymal stem cells from chicken bone marrow. Cell Tissue Bank. 2013, 14, 437-451. [CrossRef] [PubMed]

37. Gong, X.; Hou, L.; Bai, C.; Jin, D.; He, X.; Guan, W.; Ma, Y. Isolation and biological characteristics of chicken adipose-derived progenitor cells. DNA Cell Biol. 2011, 30, 453-460. [CrossRef] [PubMed]

38. Bjorkhem, I.; Meaney, S.; Diczfalusy, U. Oxysterols in human circulation: Which role do they have? Curr. Opin. Lipidol. 2002, 13, 247-253. [CrossRef] [PubMed]

39. Kim, W.K.; Meliton, V.; Amantea, C.M.; Hahn, T.J.; Parhami, F. 20(S)-hydroxycholesterol inhibits PPARgamma expression and adipogenic differentiation of bone marrow stromal cells through a hedgehog-dependent mechanism. J. Bone Miner. Res. Off. J. Am. Soc. Bone Miner. Res. 2007, 22, 1711-1719. [CrossRef] [PubMed]

40. Kha, H.T.; Basseri, B.; Shouhed, D.; Richardson, J.; Tetradis, S.; Hahn, T.J.; Parhami, F. Oxysterols regulate differentiation of mesenchymal stem cells: Pro-bone and anti-fat. J. Bone Miner. Res. Off. J. Am. Soc. Bone Miner. Res. 2004, 19, 830-840. [CrossRef] [PubMed]

41. Kim, W.-K.; Meliton, V.; Tetradis, S.; Weinmaster, G.; Hahn, T.J.; Carlson, M.; Nelson, S.F.; Parhami, F. Osteogenic Oxysterol, 20(S)-Hydroxycholesterol, Induces Notch Target Gene Expression in Bone Marrow Stromal Cells. J. Bone Miner. Res. 2010, 25, 782-795. [CrossRef] [PubMed]

42. Moseti, D.; Regassa, A.; Kim, W.-K. Molecular Regulation of Adipogenesis and Potential Anti-Adipogenic Bioactive Molecules. Int. J. Mol. Sci. 2016, 17, 124. [CrossRef] [PubMed]

43. Aghaloo, T.L.; Amantea, C.M.; Cowan, C.M.; Richardson, J.A.; Wu, B.M.; Parhami, F.; Tetradis, S. Oxysterols enhance osteoblast differentiation in vitro and bone healing in vivo. J. Orthop. Res. Off. Publ. Orthop. Res. Soc. 2007, 25, 1488-1497. [CrossRef] [PubMed]

44. Parhami, F.; Mody, N.; Gharavi, N.; Ballard, A.J.; Tintut, Y.; Demer, L.L. Role of the cholesterol biosynthetic pathway in osteoblastic differentiation of marrow stromal cells. J. Bone Miner. Res. Off. J. Am. Soc. Bone Miner. Res. 2002, 17, 1997-2003. [CrossRef]

45. Zhu, H.; Guo, Z.K.; Jiang, X.X.; Li, H.; Wang, X.Y.; Yao, H.Y.; Zhang, Y.; Mao, N. A protocol for isolation and culture of mesenchymal stem cells from mouse compact bone. Nat. Protoc. 2010, 5, 550-560. [CrossRef] [PubMed]

46. Parhami, F.; Jackson, S.M.; Tintut, Y.; Le, V.; Balucan, J.P.; Territo, M.; Demer, L.L. Atherogenic diet and minimally oxidized low density lipoprotein inhibit osteogenic and promote adipogenic differentiation of marrow stromal cells. J. Bone Miner. Res. Off. J. Am. Soc. Bone Miner. Res. 1999, 14, 2067-2078. [CrossRef]

47. Gregory, C.A.; Gunn, W.G.; Peister, A.; Prockop, D.J. An Alizarin red-based assay of mineralization by adherent cells in culture: Comparison with cetylpyridinium chloride extraction. Anal. Biochem. 2004, 329, 77-84. [CrossRef]

48. Parhami, F.; Morrow, A.D.; Balucan, J.; Leitinger, N.; Watson, A.D.; Tintut, Y.; Berliner, J.A.; Demer, L.L. Lipid oxidation products have opposite effects on calcifying vascular cell and bone cell differentiation. A possible explanation for the paradox of arterial calcification in osteoporotic patients. Arterioscler. Thromb. Vasc. Biol. 1997, 17, 680-687. [CrossRef]

49. Regassa, A.; Kim, W.K. Effects of oleic acid and chicken serum on the expression of adipogenic transcription factors and adipogenic differentiation in hen preadipocytes. Cell Biol. Int. 2013, 37, 961-971. [CrossRef]

50. Sławińska, A.; Brzezińska, J.; Siwek, M.; Elminowska-Wenda, G. Expression of myogenic genes in chickens stimulated in ovo with light and temperature. Reprod. Biol. 2013, 13, 161-165. [CrossRef]

51. Freeman, B.T.; Jung, J.P.; Ogle, B.M. Single-Cell RNA-Seq of Bone Marrow-Derived Mesenchymal Stem Cells Reveals Unique Profiles of Lineage Priming. PLoS ONE 2015, 10, e0136199. [CrossRef] [PubMed] 
52. Dominici, M.; Le Blanc, K.; Mueller, I.; Slaper-Cortenbach, I.; Marini, F.; Krause, D.; Deans, R.; Keating, A.; Prockop, D.; Horwitz, E. Minimal criteria for defining multipotent mesenchymal stromal cells. The International Society for Cellular Therapy position statement. Cytotherapy 2006, 8, 315-317. [CrossRef] [PubMed]

53. Li, A.; Hokugo, A.; Segovia, L.A.; Yalom, A.; Rezzadeh, K.; Zhou, S.; Zhang, Z.; Parhami, F.; Stappenbeck, F.; Jarrahy, R. Oxy133, a novel osteogenic agent, promotes bone regeneration in an intramembranous bone-healing model. J. Tissue Eng. Regen. Med. 2015. [CrossRef] [PubMed]

54. Jeon, E.J.; Lee, K.Y.; Choi, N.S.; Lee, M.H.; Kim, H.N.; Jin, Y.H.; Ryoo, H.M.; Choi, J.Y.; Yoshida, M.; Nishino, N.; et al. Bone morphogenetic protein-2 stimulates Runx2 acetylation. J. Biol. Chem. 2006, 281, 16502-16511. [CrossRef]

55. Komori, T. Regulation of osteoblast differentiation by transcription factors. J. Cell. Biochem. 2006, 99, 1233-1239. [CrossRef]

56. Dwyer, J.R.; Sever, N.; Carlson, M.; Nelson, S.F.; Beachy, P.A.; Parhami, F. Oxysterols are novel activators of the hedgehog signaling pathway in pluripotent mesenchymal cells. J. Biol. Chem. 2007, 282, 8959-8968. [CrossRef]

57. Richardson, J.A.; Amantea, C.M.; Kianmahd, B.; Tetradis, S.; Lieberman, J.R.; Hahn, T.J.; Parhami, F. Oxysterol-induced osteoblastic differentiation of pluripotent mesenchymal cells is mediated through a PKCand PKA-dependent pathway. J. Cell. Biochem. 2007, 100, 1131-1145. [CrossRef]

58. Montgomery, S.R.; Nargizyan, T.; Meliton, V.; Nachtergaele, S.; Rohatgi, R.; Stappenbeck, F.; Jung, M.E.; Johnson, J.S.; Aghdasi, B.; Tian, H.; et al. A Novel Osteogenic Oxysterol Compound for Therapeutic Development to Promote Bone Growth: Activation of Hedgehog Signaling and Osteogenesis through Smoothened Binding. J. Bone Miner. Res. Off. J. Am. Soc. Bone Miner. Res. 2014, 29, 1872-1885. [CrossRef]

59. Hokugo, A.; Sorice, S.; Yalom, A.; Lee, J.C.; Li, A.; Zuk, P.; Jarrahy, R. In vitro study of a novel oxysterol for osteogenic differentiation on rabbit bone marrow stromal cells. Plast. Reconstr. Surg. 2013, 132, 70e-80e. [CrossRef]

60. Matsubara, Y.; Endo, T.; Kano, K. Fatty acids but not dexamethasone are essential inducers for chick adipocyte differentiation in vitro. Comp. Biochem. Physiol. Part. AMol. Integr. Physiol. 2008, 151, 511-518. [CrossRef]

61. Matsubara, Y.; Sato, K.; Ishii, H.; Akiba, Y. Changes in mRNA expression of regulatory factors involved in adipocyte differentiation during fatty acid induced adipogenesis in chicken. Comp. Biochem. Physiol. Part A Mol. Integr. Physiol. 2005, 141, 108-115. [CrossRef]

62. Tontonoz, P.; Hu, E.; Graves, R.A.; Budavari, A.I.; Spiegelman, B.M. mPPAR $\gamma$ 2: Tissue-specific regulator of an adipocyte enhancer. Genes Dev. 1994, 8, 1224-1234. [CrossRef] [PubMed]

63. Akune, T.; Ohba, S.; Kamekura, S.; Yamaguchi, M.; Chung, U.I.; Kubota, N.; Terauchi, Y.; Harada, Y.; Azuma, Y.; Nakamura, K.; et al. PPARgamma insufficiency enhances osteogenesis through osteoblast formation from bone marrow progenitors. J. Clin. Investig. 2004, 113, 846-855. [CrossRef] [PubMed]

64. Sun, H.; Kim, J.K.; Mortensen, R.; Mutyaba, L.P.; Hankenson, K.D.; Krebsbach, P.H. Osteoblast-targeted suppression of PPARgamma increases osteogenesis through activation of mTOR signaling. Stem Cells (Dayt. Ohio) 2013, 31, 2183-2192. [CrossRef] [PubMed]

65. Lecka-Czernik, B.; Gubrij, I.; Moerman, E.J.; Kajkenova, O.; Lipschitz, D.A.; Manolagas, S.C.; Jilka, R.L. Inhibition of Osf2/Cbfa1 expression and terminal osteoblast differentiation by PPARgamma2. J. Cell. Biochem. 1999, 74, 357-371. [CrossRef]

66. Spinella-Jaegle, S.; Rawadi, G.; Kawai, S.; Gallea, S.; Faucheu, C.; Mollat, P.; Courtois, B.; Bergaud, B.; Ramez, V.; Blanchet, A.M.; et al. Sonic hedgehog increases the commitment of pluripotent mesenchymal cells into the osteoblastic lineage and abolishes adipocytic differentiation. J. Cell Sci. 2001, 114, 2085-2094. [PubMed]

67. Gupta, S.; Takebe, N.; LoRusso, P. Targeting the Hedgehog pathway in cancer. Ther. Adv. Med. Oncol. 2010, 2, 237-250. [CrossRef]

68. Chiang, C.; Litingtung, Y.; Lee, E.; Young, K.E.; Corden, J.L.; Westphal, H.; Beachy, P.A. Cyclopia and defective axial patterning in mice lacking Sonic hedgehog gene function. Nature 1996, 383, 407-413. [CrossRef]

69. St-Jacques, B.; Hammerschmidt, M.; McMahon, A.P. Indian hedgehog signaling regulates proliferation and differentiation of chondrocytes and is essential for bone formation. Genes Dev. 1999, 13, 2072-2086. [CrossRef] 
70. Nakamura, T.; Aikawa, T.; Iwamoto-Enomoto, M.; Iwamoto, M.; Higuchi, Y.; Pacifici, M.; Kinto, N.; Yamaguchi, A.; Noji, S.; Kurisu, K.; et al. Induction of osteogenic differentiation by hedgehog proteins. Biochem. Biophys. Res. Commun. 1997, 237, 465-469. [CrossRef]

71. Wang, C.; Shan, S.; Wang, C.; Wang, J.; Li, J.; Hu, G.; Dai, K.; Li, Q.; Zhang, X. Mechanical stimulation promote the osteogenic differentiation of bone marrow stromal cells through epigenetic regulation of Sonic Hedgehog. Exp. Cell Res. 2017. [CrossRef] [PubMed]

72. Yuasa, T.; Kataoka, H.; Kinto, N.; Iwamoto, M.; Enomoto-Iwamoto, M.; Iemura, S.; Ueno, N.; Shibata, Y.; Kurosawa, H.; Yamaguchi, A. Sonic hedgehog is involved in osteoblast differentiation by cooperating with BMP-2. J. Cell. Physiol. 2002, 193, 225-232. [CrossRef] [PubMed]

73. Lin, F.X.; Du, S.X.; Liu, D.Z.; Hu, Q.X.; Yu, G.Y.; Wu, C.C.; Zheng, G.Z.; Xie, D.; Li, X.D.; Chang, B. Naringin promotes osteogenic differentiation of bone marrow stromal cells by up-regulating Foxc2 expression via the IHH signaling pathway. Am. J. Transl Res. 2016, 8, 5098-5107.

74. Johnson, J.S.; Meliton, V.; Kim, W.K.; Lee, K.B.; Wang, J.C.; Nguyen, K.; Yoo, D.; Jung, M.E.; Atti, E.; Tetradis, S.; et al. Novel oxysterols have pro-osteogenic and anti-adipogenic effects in vitro and induce spinal fusion in vivo. J. Cell. Biochem. 2011, 112, 1673-1684. [CrossRef]

75. Hokugo, A.; Sorice, S.; Parhami, F.; Yalom, A.; Li, A.; Zuk, P.; Jarrahy, R. A novel oxysterol promotes bone regeneration in rabbit cranial bone defects. J. Tissue Eng. Regen. Med. 2016, 10, 591-599. [CrossRef] [PubMed]

76. Amantea, C.M.; Kim, W.-K.; Meliton, V.; Tetradis, S.; Parhami, F. Oxysterol-Induced Osteogenic Differentiation of Marrow Stromal Cells is Regulated by Dkk-1 Inhibitable and PI3-Kinase Mediated Signaling. J. Cell. Biochem. 2008, 105, 424-436. [CrossRef]

77. Suh, J.M.; Gao, X.; McKay, J.; McKay, R.; Salo, Z.; Graff, J.M. Hedgehog signaling plays a conserved role in inhibiting fat formation. Cell Metab. 2006, 3, 25-34. [CrossRef]

78. Song, L.; Tuan, R.S. Transdifferentiation potential of human mesenchymal stem cells derived from bone marrow. Faseb J. Off. Publ. Fed. Am. Soc. Exp. Biol. 2004, 18, 980-982. [CrossRef]

79. Hong, J.-H.; Hwang, E.S.; McManus, M.T.; Amsterdam, A.; Tian, Y.; Kalmukova, R.; Mueller, E.; Benjamin, T.; Spiegelman, B.M.; Sharp, P.A.; et al. TAZ, a Transcriptional Modulator of Mesenchymal Stem Cell Differentiation. Science 2005, 309, 1074. [CrossRef]

80. Abdallah, B.M.; Jensen, C.H.; Gutierrez, G.; Leslie, R.G.; Jensen, T.G.; Kassem, M. Regulation of human skeletal stem cells differentiation by Dlk1/Pref-1. J. Bone Miner. Res. Off. J. Am. Soc. Bone Miner. Res. 2004, 19, 841-852. [CrossRef]

81. Gang, E.J.; Jeong, J.A.; Hong, S.H.; Hwang, S.H.; Kim, S.W.; Yang, I.H.; Ahn, C.; Han, H.; Kim, H. Skeletal myogenic differentiation of mesenchymal stem cells isolated from human umbilical cord blood. Stem Cells (Dayt. Ohio) 2004, 22, 617-624. [CrossRef] [PubMed]

82. Braun, T.; Arnold, H.H. Myf-5 and myoD genes are activated in distinct mesenchymal stem cells and determine different skeletal muscle cell lineages. EMBO J. 1996, 15, 310-318. [CrossRef] [PubMed]

83. Gang, E.J.; Bosnakovski, D.; Simsek, T.; To, K.; Perlingeiro, R.C. Pax3 activation promotes the differentiation of mesenchymal stem cells toward the myogenic lineage. Exp. Cell Res. 2008, 314, 1721-1733. [CrossRef] [PubMed]

84. Yin, H.; Price, F.; Rudnicki, M.A. Satellite Cells and the Muscle Stem Cell Niche. Physiol. Rev. 2013, 93, $23-67$. [CrossRef]

85. Sabourin, L.A.; Rudnicki, M.A. The molecular regulation of myogenesis. Clin. Genet. 2000, 57, 16-25. [CrossRef]

86. De Bari, C.; Dell'Accio, F.; Vandenabeele, F.; Vermeesch, J.R.; Raymackers, J.-M.; Luyten, F.P. Skeletal muscle repair by adult human mesenchymal stem cells from synovial membrane. J. Cell Biol. 2003, 160, 909-918. [CrossRef]

87. Jalali Tehrani, H.; Parivar, K.; Ai, J.; Kajbafzadeh, A.; Rahbarghazi, R.; Hashemi, M.; Sadeghizadeh, M. Effect of Dexamethasone, Insulin and EGF on the Myogenic Potential on Human Endometrial Stem Cell. Iran. J. Pharm. Res. IJPR 2014, 13, 659-664.

88. Yablonka-Reuveni, Z.; Day, K.; Vine, A.; Shefer, G. Defining the transcriptional signature of skeletal muscle stem cells. J. Anim. Sci. 2008, 86, E207-E216. [CrossRef]

89. Collins, C.A.; Olsen, I.; Zammit, P.S.; Heslop, L.; Petrie, A.; Partridge, T.A.; Morgan, J.E. Stem cell function, self-renewal, and behavioral heterogeneity of cells from the adult muscle satellite cell niche. Cell 2005, 122, 289-301. [CrossRef] 
90. Lindon, C.; Montarras, D.; Pinset, C. Cell cycle-regulated expression of the muscle determination factor Myf5 in proliferating myoblasts. J. Cell Biol. 1998, 140, 111-118. [CrossRef]

91. Zammit, P.S.; Partridge, T.A.; Yablonka-Reuveni, Z. The skeletal muscle satellite cell: The stem cell that came in from the cold. J. Histochem. Cytochem. Off. J. Histochem. Soc. 2006, 54, 1177-1191. [CrossRef] [PubMed]

Publisher's Note: MDPI stays neutral with regard to jurisdictional claims in published maps and institutional affiliations.

(C) 2020 by the authors. Licensee MDPI, Basel, Switzerland. This article is an open access article distributed under the terms and conditions of the Creative Commons Attribution (CC BY) license (http://creativecommons.org/licenses/by/4.0/). 